Historic, Archive Document

Do not assume content reflects current scientific knowledge, policies, or practices. 
Buy From This Catalog-Get More

For Your Money

\section{GRANITE STATE}

NURSERIES, INC.

HAMPTON ROAD

\section{Exeter, N. H.}

J. A. Tufts, Jr., Mgr.

Phone 178-Y

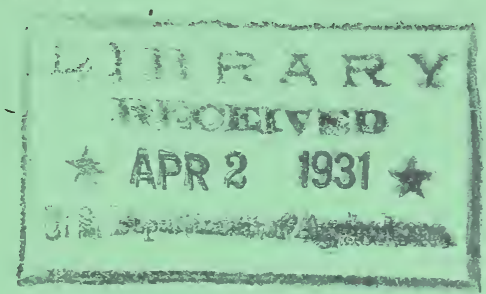

1931

Hardy New England Grown

Best By Test

Quality-Service-Satisfaction-New England Industry - Reasonable Prices-Acclimated Stock

(See Inside Back Cover for Index) 


\section{LOCATION OF NURSERIES}

One mile from the "Square" at Exeter, on High Street, the Hampton road, - the main highway from Manchester to the beach. Six miles from Hampton and the Lafayette Highway (running from Boston to Portland, via Newburyport and Portsmouth). 32 miles from Manchester, 14 miles from Portsmouth, 10 miles from Amesbury, 18 miles from Haverhill, and 20 miles from Dover.

\section{CASH DISCOUNT}

When cash in full accompanies order, a $10 \%$ discount may be taken on Spring orders received before March 24 , and a $5 \%$ discount on orders received before April $7 \mathrm{th}$.

$\mathbf{2 5 \%}$ of the amount should accompany all orders, the balance to be sent at shipping time, otherwise shipment will be C. O. D.

Prices quoted are for stock at the nurseries or delivered to our railroad station. There is no charge for packing.

We are always ready and willing to correct errors on our part, but we are at no time responsible for any amount greater than the original sales price. All claims for damage in transit must be made to the transportation company. Our responsibility ceases on delivery to the carrier.

We book all orders with the understanding that same shall be void should injury befall stock from fire, error in count, or other causes beyond our control.

\section{TIME OF PLANTING}

All stock listed in this catalog may be transplanted in the Spring. Peonies, Irises, and Evergreens may also be transplanted in August or later.

Perennials and pot-grown strawberry plants may also be moved in September or later.

Apple Trees, Small Fruits, Grape-Vines, and most varieties of Shade Trees, Shrubs, and Vines may also be transplanted in October or November.

The following

\section{CERTIFICATE OF INSPECTION}

Will accompany all shipments made from our Nurseries:-

\section{STATE OF NEW HAMPSHIRE}

Department of Agriculture

Division of Nursery Inspection

This certifies that inspection of the nursery of Granite State Nurseries, Inc., at Exeter, N. H., was completed......... The attached stock was included within the above inspection and is apparently free from dangerous insects or diseases.

(Signed) W. C. O'KANE, State Nursery Inspector.

\section{SUNDAYS}

We do not make a practice of filling orders on Sunday. As an accommodation, however, we are glad to get up orders on Saturday which may, by arrangement, be called for on Sunday. Our hours of business are : Week days, 7 A. M. to 5 P. M. Visitors are always welcome. 


\section{MANAGER'S MESSAGE}

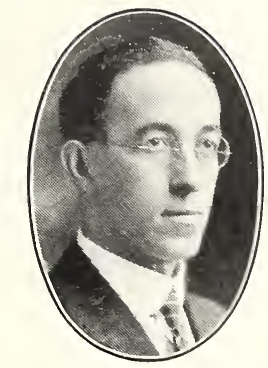

JAMES A. TUFTS, JI. Manager

\section{IGAIN WE SAY: "GREETINGS TO ALL"}

We want our customers to know how much we appreciate the opportunity to serve them. We are grateful for the continued patronage of our old friends and we welcome the chance to make new friends. To please our customers, both with the quality of our goods and our service, is our constant endearor. Should anything which we send you fail to be satisfactory on its arrival, please adrise us at once so that we may have the opportunity of making it satisfactory at that time.

Remember: "When you are pleased-we are pleased."

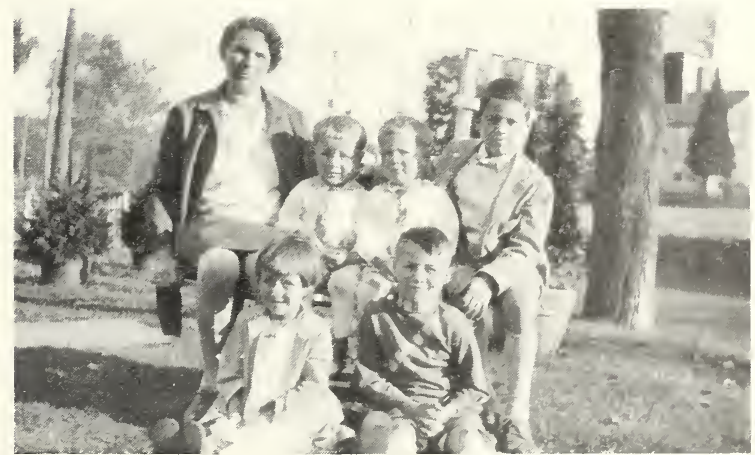

Many of our friends have followed with interest the suap-shots of the children which have appeared on this jagr. Here we present a family group including Mrs. T'ufts. 'The' twins, Kenneth and Charles are on the settee with Mrs. Tufts and Arthur, and Fleanor and Ralph are seated in the foreground. 


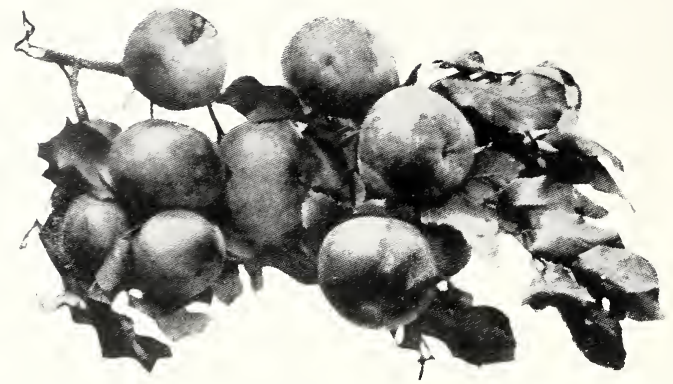

\section{FRUIT TREES}

In the Annual (Outlook Report. dated February 2, 1931. the U. S. Department of Agriculture says, "Market prospects for apples justify the maintenance of the present number of trees in Commercial orchards, and possibly some increase." Apparently the Department feels that the prices in 1930 were the result of an unusually heary erop combined with general business depression.

Last vear we told you about one of our austomers who planted ofis of our trees and only lost three. 'This year we have a better record, only one tree lost out of 625 on one order. And the 624 , or og.s per cent, made a very satisfactory growth. If our trees can do this for one man they can for another-a very good reason for placing your order with us, for New England-grown trees.

We strongly urge planting only the $5-7 \mathrm{ft}$. trees, $11 / 1$; in. in dianeter, as these are strong, vigorous trees which have never been stunted and which will surpass any of the linhter arades of trees.

\section{APPLES}

\section{('WR'TIFIEI) 'TRLE-TO-NAME}

(By the Massachusetts Fruit Growers' Asso.)

$2-3$ Yr. Trees, $5-7$ ft., 60 each ; $\$ 5.00$ for $10 ; \$ .35 .00$ 16el 100 .

\section{INCFR'TIFIED}

$2-9$ Yr. Tress, $5-7 \mathrm{ft} .50$ each ; $\$ 4.50$ for $10 ; \$ 30.00$ fer 100 .

Fxtra size Especially selected. 75e each ; $\$ 6.50$ for 10 .

5 or more of one variety, at the 10 rate, 50 at the 100 rate.

\section{SUMMER MPPIES}

L-Yellow Transparent. Productive roung benrer. July.

Larly Harvest. Lalde, yellow. Cooking and eating.

L-Red Istrachan. Large. juir.y, and wood. August.

Sweet Bough. (August Sweet.) Very sweet. Large.

L-William's Favorite. IRed. frood for market or home. Alinist.

L-Duchess of Oldemburs. Striped red. Prolific. Very good. September. Especially hardy. Good for market or liome.

Porter. An old farorite for eating.

\section{FALI OIR AUTUMN MPPLES}

L-Cravenstein. Yellow striped red. Juicy. One of the bost for rooking or eating. September-October.

L-Red Gravenstein. Similar to the old-fashioned Gravenstein, except in color. (Not rertified.) $75 \mathrm{c}$ each.

(i-Wealthy. Dark red. Iroductive. Good seller. OctoberNovember.

G-McIntosh Red. Fine quality. Hardy, productive. October-January.

I-Snow (Fameuse). Red with very white flesh. Hardy. Very good. October-January.

Hubbardston. Red. Popular old variety. NovemberFebruary.

Pomd Sweet. Yellow, A favorite for baking. NovemberFeloruary.

See page 6 for meaning of $I$, and $G$. 


\section{WINTER IPPLEN}

G-Cortand. Of the Melntosh type and flavor, I promising new apple for New England. Originated by the N. Y. Experimental Station.

Opalescent. Red. Very showy and attractive. oretoberJanuary.

Winter Banana. Yellow and red. To eat or balie. Norember-February.

Baidwin. Red. Still leads in New England. Now-dpril.

I-Rhode Island Greening. Cooking or dessert. NovemberMarch.

L-Northern Spy. Striped red. Juicy. Good. Nor,-March. Wagener, Red. Cooking and eating. December-March.

Stayman Winesap. Late-keeping. Red and yellow.

L-Tolman Sweet. Best for winter baking. Dec-March. Delicious. Red. Very good for eating. I erember-April.

Roxbury Russet. Late keeper. Productive. January-June.

\section{CRIB APIIES}

These varioties are very hardy. The fruit is excellent for jelly and finds ready sale on the market. The trees are very ornamental. Prices same as other apples.

L-Transcendent. Yellow and red. Young bearer. Sent L-Hyslop. Large. Good keeper. Deep red. Sept.ort.

\section{IUIIRF IPPLE TREES}

:3-4 ft.. \$1.00 each; 3 or more. s.je each; 10 for $\$ 7.50$ For shipment by l'arcel Post, add 10, per tree.

Delicious-Northern Spy-Baldwin-McIntosh Red-Cortland-Istrachan-Wealthy-Duchess-Cirime's Golden

\section{Sweet Bough}

\section{QUINCES}

4-5 ft.. \$1.00 each; 3 or more. s.ic each.

Champion. Ielicions flavor for preserves. Young bearer. Orange, Bright vellow. Vigorous and productive.

\section{CHERRIES}

The first thee varieties are very hardy, woductive, and profitable, and very popular for camning. Sweet cherrios shomld be planted on soils and location suitable for peaches and will there prove very protitable. For pollination, two or more varieties of Sweet Cherries shomld be planted together.

\section{Solir}

2 Ir. Trees, $5-7$ ft.. \$1.00 each ; any 2 ol 4. s.oc each. $\$ 7.50$ for any 10: any 5 or mole. at 10 rate.

L-Early Richmond. Iiright red. Slightly aciel. IIardy.

(i-Montmorency. I)ark red. Large. slightly acid. Fery havely.

I-English Morello. Blackish rofl. slightly acitl. Very hardy and productive.

\section{Sweet}

Same mices as Somr ( Therries.

L-Black Tartarian. Sweet, large and luseions.

Sapoleon Bigarreau. Sweet. Yellow and pink. Jarre.

L-Governor Wood. Siveet. Yellow and red. Large. Juicy L-Windsor. I,iver color. Fine quality. IIardy.

see page 6 for meaning of $I$, and 6 .

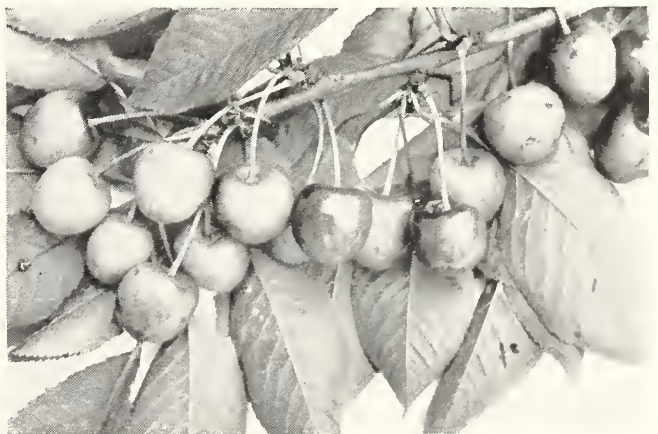




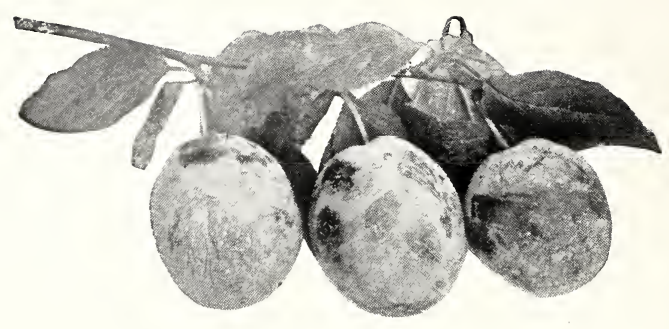

\section{PLUMS}

\section{CHR'TIFIEI) TRUE-TO-NMME}

2 Yr. Trees, 5-6 ft., $\$ 1.00$ each; 3 or more, 7fc each. Any 10 for $\$ 6.00$.

Varieties arranged in order of earliness.

For best results plant more than one variety.

\section{JAPANESE TYPE}

G-Red June. Medium size, cherry red.

G-Abumdance. Cherry red, sweet, rich. Eating or canning. G-Burbank. Cherry red. Enormously productive. Satsuma. Purple and red, with blue bloom. Small. October Purple. Large, good grower, good quality.

\section{EUROPEAN TYPE}

Bradshaw. Large, reddish yellow, dessert variety. Early. Lombard. Purple, medium size, good quality.

Shropshire Damson. Deep blue, canning variety. Late.

\section{PEARS}

\section{CERTIFIED TRUE-TO-NAME}

2 Yr. Trees, 5-7 ft., $\$ 1.00$ each ; any 3 or 4 , 85e each $\$ 7.50$ for any 10 ; any 5 or more, at 10 rate.

For best results plant more than one variety.

(;-Clapp's Favorite. Best early pear. August.

L-Bartlett. Very popular. September.

L-Beurre Bosc. A Fall variety. Very profitable for market. Melting. Pleasant. Not certified.

Seckel. Fall. Rich and highly flavored. Small.

Worden Seckel. Medium size. Juicy, buttery.

Duchess (d'Angouleme.) Large, greenish yellow. October. I-Sehldon. Large, round, russet. Rich and spicy. Nov. L-Benre d'Anjou. Iarge, high quality. December.

I awrence. Large, tender, yellow. December.

\section{DWVARF PEAR TREES}

Dwarf pear trees are often better for the small homestead or garden and for such we recommend them. They bear good crops in two or three years from setting out and the fruit is exceptionally fine in quality and size.

Fine 2 Yr. Trees, $3-5$ ft., $\$ 1.00$ each; 3 or more 850 vich; a11y 10 for $\$ 7.50$.

\section{Clapp's Favorite-Bartlett-I) \\ Sheldon}

For shipment by Pareel Post, add 10c per tree.

See above list for description of varieties.

\section{PEACHES}

\section{CFRTIFIEI) TRUE-TO-NAME}

Is with all our fruit trees, the varieties of peaches offered here have been carefully selected as the best for New Hogland. They are all Free-stone and arranged in the order of their ripening.

t-f ft. Trees, 40c each; $\$ 3.50$ for $10 ; \$ 25.00$ per 100 .

$\therefore$ of one variety at 10 rate.

For shipment by Parcel Post, add 5c per tree.

I-Cireensboro. Yellow-white overlaid with red. Harly in wood and bud.

Champion. White with red cheek. Large. Delicious. 
I-Rochester. A new variety highly praised by some authorities. Earliest yellow. Iarge and pretty.

Carmen. Creamy white with red blush. Great for home use or market.

Early Crawford. Very popular. Yellow. Good quality. L-Belle of Georgia. White overlaid with red. Productive.

I-J. H. Hale. Very large. Deep yellow.

L-Elberta. Large golden yellow. Juicy, rich. Gool quality. Probably the most popular peach in New England. Special quotations in quantities.

We sell Peach Baskets. When you are ready to buy, write us for prices.

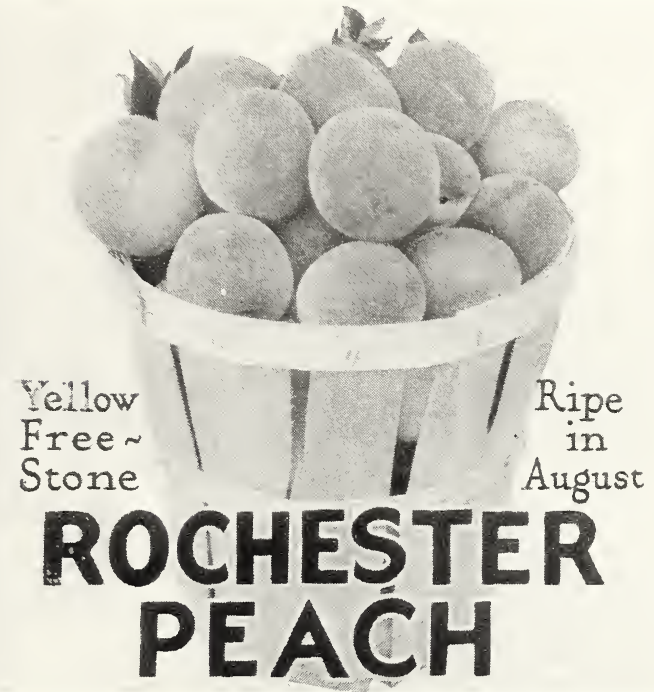

\section{FRUIT TREES BY MAIL}

With the exception of peach trees, only Dwarf Fruit Trees can be sent by mail.

\section{GRAPE-VINES}

Plant on light loamy to sandy soils and in sumny locations. Train on trellis or southern side of fence, barn, or house. Profitable and easy to raise.

2 Yr. Vines, 30c each; $\$ 1.25$ for 5, except as noted.

On orders for 5 or more grape vines, we pay the postage except on C. O. D. shipments. For less than 5 vines, add se per vine for postage.

\section{BLUE GRAPES}

Moore's Farly. One of the very best for New England. Worden. Similar to Concord but larger, earlier, better. Concord. Still a desirable variety and a great favorite. Campbell's Early. Large and handsome.

\section{RED GRAPES}

Brighton. Bunch and berry, large. Quality fine.

Delaware. Small, fine flavor, popular.

\section{WHITE GRAPES}

Niagara. Bunch and berry, large. Fine flavor.

Green Mountaiı. Very hardy, desirable variety. $50 \mathrm{c}$ each. 


\section{RASPBERRIES \\ CHIEF}

$\$ 1.50$ per doz.; $\$ 2.50$ for $25 ; \$ \$ .00$ for 100 . 5c per dozen additional if by mail.

A new variety originated by the Minnesota Fruit Breeding Farm, originators of Latham. This variety has been under test a number of years. and it has considerably outrielded Latham the last two years. It is a trifle smaller than Latham. but a slightly better berry and somewhat firmer. Ripens nearly a week earlier and is a good variety to prolong the season. Chief is said to be the hardiest of the desirable new varieties.

\section{G-L. THНАМ}

We were one of the first nurseries to offer I atham Raspberry plants. The variety has been with us long enough now to demonstrate its superior hardiness and productivity without sacrifice of quality. We have no hesitation in recommending it for general plantnig.

12 plants for $\$ 1.00: 25$ for $\$ 1.50 ; 100 \mathrm{for} \$ 5.00 ; \$ 35.00$ per 1000. 5c per dozen additional if by mail.

\section{FOLLOWING; VARIETIES}

75 ( wer doz.: \$1.25 for 25: $\$ 3.50$ for $100 ; \$ 30.00$ per 1000 . 5c per dozen additional if by mail.

L-St. Regis. In a class by itself. Bright red, fine quality. Very early. With good cultivation, produces fruit from Jnne to October. Fery profitable.

L-Cuthbert. The great commercial red raspberry. Good quality. Good cropper. Vigorous grower.

1-Herbert. Next to Latham in hardiness. Large red, good quality.

PInm-Farmer. The best black-cal. Early. Good for canning or preserving.

\section{COLUMBIAN}

$\$ 1.50$ per doz. ; $\$ 2.50$ for $25 ; \$ \$ .00$ for 100 . $5 \mathrm{c}$ per dozen additional if by mail.

Columbian. Purple. A very good cropper and one of the best for preserving. This variety does not spread and so can be kept under control very easily. We have found that tip-plants are not satisfactory so are offering one-year transplants. Raspberries are easy to raise. and they sell readily.

Set the plants $3 \mathrm{ft}$. anart in the row. and rows $5 \mathrm{ft}$. apart. Use chemical fertilizer, with possibly wood ashes. and keep well cultivated.

\section{BLACKBERRIES}

75c per doz.; $\$ 1.25$ for $25: \$ 4.00$ for $100: \$ 35.00$ per 1000 sc per dozen additional if by mail.

L-Suyder. Very hardy. productive variety. The best.

EIdorado. Fxcellent quality. productive. Fairly hardy.

Set plants same as raspberries. except that it is desirable to make the rows a little finther apart.

\section{Meaning of $L$ and $G$ Varieties for Maine}

With the idea of helping those persons who are considering planting fruit trees or small fruits in Maine, we asked the Head of the Department of Horticulture at the University to indicate those varieties which he considered suitable for Maine planting. These we have marked as follows :

G-meaning suitable for General Use.

I- meaning suitable for Limited Ise.

Let us know your preference and we will ship to suit your convenience.

\section{DISTANCES OF PLANTING}

Apples, 30-40 feet. Peaches. 16-20 feet. Pears, 20-25 feet. I'lums. 16-20 feet. Quinces, 10-12 feet. (irape-Vines, $8-12$ feet. Asparagus, $1 \frac{1}{2} \times 3$ feet. Rhubarb, $1 \frac{1}{2}$ feet.
Sweet Cherries, 20-25 feet.

Sour Cherries, 16-20 feet.

Blackberries, $4 \times 17$ to $6 \times 8 \mathrm{ft}$. Red Raspberries, $3 \times 5$ feet.

Black Raspberries, $3 \times 6$ feet. Strawberries, garden, 1-3 ft.. field. 1-4 ft.

Dwarf Trees, 20 feet. 


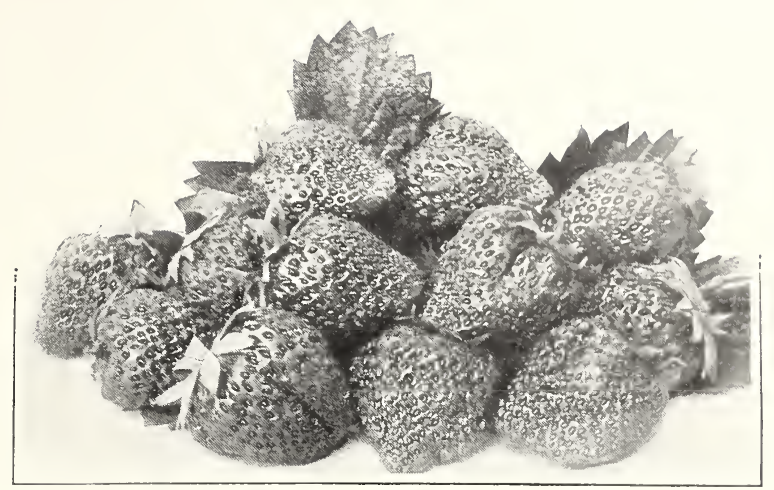

STRAWBERRIES

Every garden and farm should raise a good supply for use fresh and for camning. They make a very wonderful sauce or preserve. Incidentally, they are a profitable crop to raise for market. In planting, choose well-prepared gromnd, free from witch grass, and set the plants with the crown or bud just at the surface of the ground. Set the plants $1 \mathrm{ft}$. apart, with the rows at least $3 \mathrm{ft}$. apart.

Our plants are what we call "Good-as-Grow" Brand. Order early and set as early as possible. Please specify if we may substitute, if sold out of any variety ordered.

\section{STANDARD VARIETIES}

All perfect flowering, except Sample.

$50 \mathrm{c}$ for 25 plants; $75 \mathrm{c}$ for $50 ; \$ 1.25$ for $100 ; \$ 5.00$ for $500 ; \$ 9.00$ for 1000 .

We pay postage on lots of 500 or less except on C. O. D. shipments.

Wilson. Early. An old variety of good flavor and quality. Very popular with some of our local growers.

Howard 17. For a good all-around variety for home or market, this has no superior. Among its many good qualities are the following: Earliness, good size, color, shape, shipping qualities, drought-resistance, productiveness, disease resistance, supply of pollen and lengtl of fruiting season.

Senator Dunlap. Early to mid-season. A well-established old variety which gives an abundance of satisfaction.

Abington. Mid-season. Being deep-rooted, withstands drought. Large, bright red berries that ripen all over at once. Good for home or market.

First Quality. Mid-season. Very attractive berry, long and pointed. Sells very rapidly and is all that its name implies.

Brandywine. Late. A vigorous grower yielding high quality, large berries. An old favorite.

Sample. Late. Bright red and attractive. A very desirable variety, but must be planted with other varieties for pollenizing. (We recommend Abington).

Aroma. Late. Produces a big crop of extra large, good quality berries. Is very attractive and is a good variety to prolong the season.

Pearl. Very late. Yields large, dark red, firm berries.

Prices quoted here are for Spring of 1931, for April and May shipment.

For Fall Planting, we offer

Pot-Grown Howard 17

At $\$ 1.50$ per 25 by Parcel Post. $\$ 5.00$ per 100 by Express collect. 


\section{STRAWBERRY PLANTS \\ EVERBEARING VARIETIES}

These are very desirable for the home garden or for the man or woman who has a good local market like a summer hotel. 'Their novelty has worn off, they have proved themselves worthy, and have come to stay.

(i5c for 25 plants; $\$ 1.00$ for $50 ; \$ 2.00$ for 100 .

$\$ 8.00$ for $500 ; \$ 15$ for 1000 (Except Mastodon)

We Pay the Postage on lots of 500 or less except on C. O. D. shipments.

Progressive. Better quality than Mastodon. Dark Glossy red. Earliest spring berry and a good fruiter all season long. Cultivate and fertilize it well and it will pay for itselt many times over.

Superb. Large, dark red. A good variety to grow in hills. Iulch well, and keep cultivated, and it will produce an abundance of big berries in the spring and a good succession of them until freezing weather.

Mastodon. A new variety which produces a large quantity, both Spring and Fall, of big red berries. Best commercial Everbearer. $\$ 1.00$ for 25 plants; $\$ 3.00$ for $100 ; \$ 18.00$ for 1000 .

\section{RHUBARB ROOTS, "PIE PLANT"}

15̄c each : $\$ 1.00$ for 10 . By mail, 20c each; $\$ 1.25$ for 10 . Limaeus. The standard large, early variety for home or market.

Rhubarb is a good spring tonic. It is easy to raise, and any surplus may be canned for winter use as saucse or for pies.

\section{ASPARAGUS ROOTS}

Every gardener and farmer should raise his own asparagus, even if all he has is a few plants in a row alongside the vegetable garden, out of the way of the plow, but where the wheel-harrow can be run over them in early spring. Isparagus should be set only on well-prepared ground which is free from witch grass. Ordinarily we recommend spring planting for asparagus. We have, however, at least one customer-friend who has set the roots in the fall with good success, and we should like to hear from others who have tried fall-planting. Upon request we will gladly mail more complete instructions on starting an Asparagus Bed.

The best variety of all is Mary. Washington. Consequently we are raising only this variety. Why not plant the best and why not let us fill your order with fresh-dug roots at reasonable prices?

1 Yr. Roots: 50c for 25; 75c for 50; $\$ 1.50$ for 100 ; $\$ 6.00$ for $500 ; \$ 10.00$ for 1000 .

By mail: $55 \mathrm{c}$ for 25 roots; $85 \mathrm{c}$ for $50 ; \$ 1.60$ for 100 ; $\$ 6.50$ for 500 .

2 Yr. Roots: 75 c for $25 ; \$ 1.00$ for $50 ; \$ 2.00$ for 100 ; $\$ 7.50$ for $500 ; \$ 15.00$ for 1000 .

By mail : Soc for $25 ; \$ 1.10$ for $50 ; \$ 2.10$ for 100 ; $\$ 5.00$ for 500 .

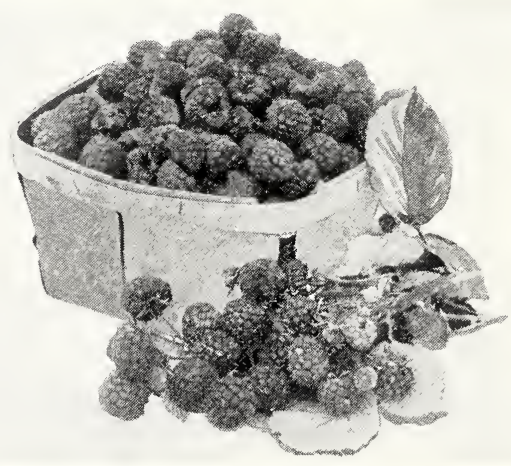

Raspberries 


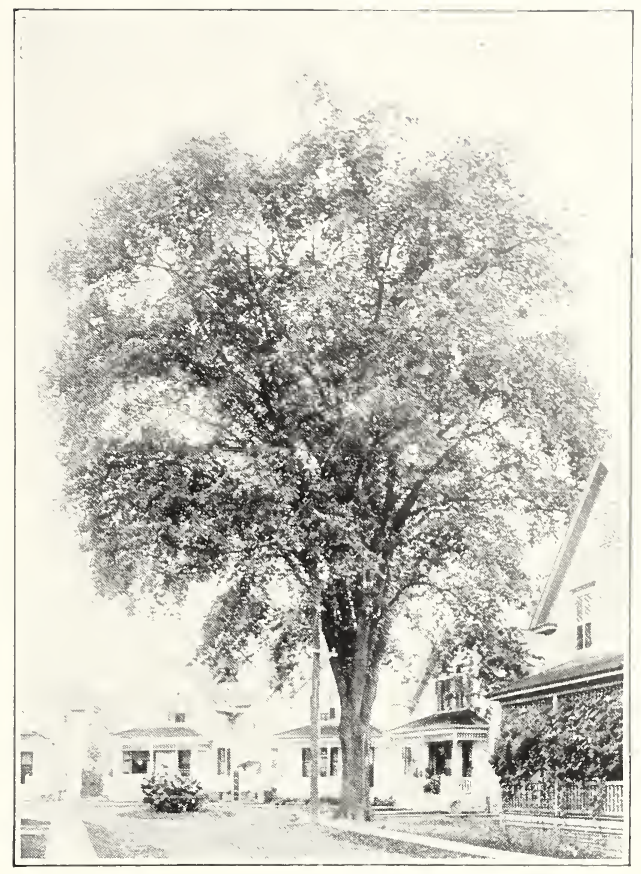

American Elm

\section{ORNAMENTAL SHADE TREES}

Ten trees of one size and one variety for nine times the price of one tree. Five trees for one half of this amount.

American Red Bud. A low growing spreading tree, covered with rose-pink flowers before the leaves come out. 4-5 ft., $\$ 1.50$.

Asl, American. Tall, healthy, rapid-growing trees. 6-8 ft., $\$ 1.50 ; 8-10$ ft., $\$ 2.00$.

Beech, Purple. Bronze-purple foliage in Spring. $2-3 \mathrm{ft}$., $\$ 4.00$.

Bircl. Cut-Leaf Weeping. Beautiful, graceful lawn trees. $5-6 \mathrm{ft} ., \$ 2.00 ; 6-8 \mathrm{ft} ., \$ 3.00$.

Birch, Paper or Canoe. The beautiful, native white variety. Well-branched, $6-8 \mathrm{ft} ., \$ 2.00 ; 8-10 \mathrm{ft} ., \$ 2.50$.

Box Elder. Rapid-growing, spreading tree which grows to height of $40-50 \mathrm{ft}$. $8 \mathrm{ft} ., \$ 1.50 ; 10 \mathrm{ft}, \$ 2.00$.

Catalpa, Bungei. Round compact heads. Inw-growing formal trees. 2-yr. heads, 5-6 ft., $\$ 2.00$.

Catalpa, Speciosa. Rapid grower with white flowers and long seed pods. Grows $40 \mathrm{ft}$. tall. $6-\mathrm{S} \mathrm{ft} ., \$ 1.25 ; 8-10$ ft., $\$ 1.50$.

Crab, Betchel's Double-Flowering. Fragrant flowers on long, drooping branches. $2-3 \mathrm{ft} ., \$ 3.00 ; 3-4 \mathrm{ft} ., \$ 1.50$.

Dogwood, White-Flowering. A beautiful small tree, witl white flowers. 2-3 ft., $\$ 1.00 ; 3-4 \mathrm{ft} ., \$ 1.25$.

Elm, American. The famous New England street tree. 6-S ft., $\$ 1.50$ each, $\$ 12.50$ per ten; 8-10 ft. $\$ 2 .(1)$ each, $\$ 18.00$ per ten; $10-12 \mathrm{ft} . . \$ 3.00$ each, $\$ 27.00$ per ten.

Elm, Moline. A new variety ; compact, rapid grower. handsome deep green foliage. $6-8 \mathrm{ft} ., \$ 2.00 ; 8-10 \mathrm{ft} . . \$ 3.00$.

Ginkgo, Maidenhair Tree. A picturesque slender lawn tree. $6-8 \mathrm{ft} ., \$ 3.50$.

Hawthorne, Paul's Scarlet. Covered with very pretty flowers in May. 5-6 ft.. $\$ 2.50$.

Horse Chestnut. Known by everybody. White flowers. $6-\mathrm{st} . . \$ 2.50$.

Larch. Beautiful light green needles. which turn bright vellow in autmn. $3 \mathrm{ft} ., \$ 1.50 ; 4 \mathrm{ft} . . \$ 2.00 ; .5 \mathrm{ft} . . \$ 2.50)$. 
ORXAMENTAI, TREES-Continued

Linden. American. Stately rapid-growing trees which grow about as tall as Sugar maples. 6-8 ft., $\$ 2.00$; $\mathrm{S}-10 \mathrm{ft}$., $\$ 0.60$.

Maple. Ish-Leaved. See Box Elder.

Maple. Bioodleaf Japanese. Bushy, dwarf, bright red trees. $12-1 \mathrm{~s}$ in., $\$ 2.50$.

Mape. cut Leat Weeping. ( Weir's). Long, hanging branches. liapid grower. S-10 ft., $\$ 2.00$.

Maple Norway. Rapid-growing street tree. $6-\mathrm{S} \mathrm{ft} ., \$ 2.50$; s-10 ft., $\$ 3.00$.

Mapue. Schwedler. Crimson foliage, changing to bronze. 6 ft., $\$ 3.50 ; 8$ ft., $\$ 4.50$.

Iaple. Silver. Large, spreading, rapid-growing. $8-10 \mathrm{ft}$. $\$ 1.50$.

Maple. Sugar or Rock. The popular street tree. S-10 ft., $\$ 2.00 ; 10-12 \mathrm{ft} ., \$ 3.00$.

Iountain Ish, European. Ornamental, scarlet fruit in fall. $\overline{5}-4$ ft., $\$ 1.25 ; 6-\mathrm{ft} ., \$ 2.00 ; \mathrm{s}-10 \mathrm{ft} ., \$ 2.50$.

Mubery, Russian. Planted for the birds especially. 6-S ft., $\$ 1.50$.

Muberry, Tea's Weeping. Small trees with drooping branches and dense, deep green foliage. Especially for lawn planting. $5-6 \mathrm{ft}$. stems, 2-vr. heads, $\$ 3.00$.

Poplar, Carolina. Quick grower, with maple-shape top. $6-\mathcal{f t} ., 50 \mathrm{c} ; \mathrm{S}-10 \mathrm{ft} ., 75 \mathrm{c} ; 10-12 \mathrm{ft}$., $\$ 1.00$.

Poplar. Lombardy. Tall, slender, rapid-grower. 6-S ft. 75c: $\$-10$ ft., $\$ 1.00 ; 10-12$ ft., $\$ 1.50$.

Plum. Purple-leaved. Very pretty small tree. $3-4 \mathrm{ft} ., 75 \mathrm{c}$; t-5 tt., $\$ 1.00$.

Willow. Golden-Barked. An upright, spreading tree which grows $30-40$ ft. tall. $6-8$ ft., $\$ 1.50 ; 8-10$ ft., $\$ 2.00$; $1:-12 \mathrm{ft} ., \$ 2.50$.

Willow. Lamel-Leaf. Upright and spreading growing tree which attains height of $20-30 \mathrm{ft}$. Makes quick effects andi is good for screens. Bushy 4-6 ft. trees, 50c; 6 ft.. $\$ 1.00 ; \mathrm{S}$ ft. $\$ 1.50$.

Willow. Thurlew. Spreading tree with long hanging branches and yellow-green bark. Attains height of $30-10$ ft. Well-branched. $6-8 \mathrm{ft} ., \$ 1.00 ; \mathrm{S} \mathrm{ft} ., \$ 1.50$.

Willow. Wisconsin, Weeping. A good weeping variety which grows 30-40 ft tall. Well-branched, $4-6 \mathrm{ft} ., 50 \mathrm{c} ; 6 \mathrm{ft}$. $\$ 1.00$; 8 ft., $\$ 1.50$.

EVERY DAY IS ARBOR DAY WITH US

Our nurseries are located right here in New England within a comparatively few miles of you, and we can get stock to you in good fresh condition-making it unnecessary for you to send away off to some other part of the country for trees. plants and bulbs.

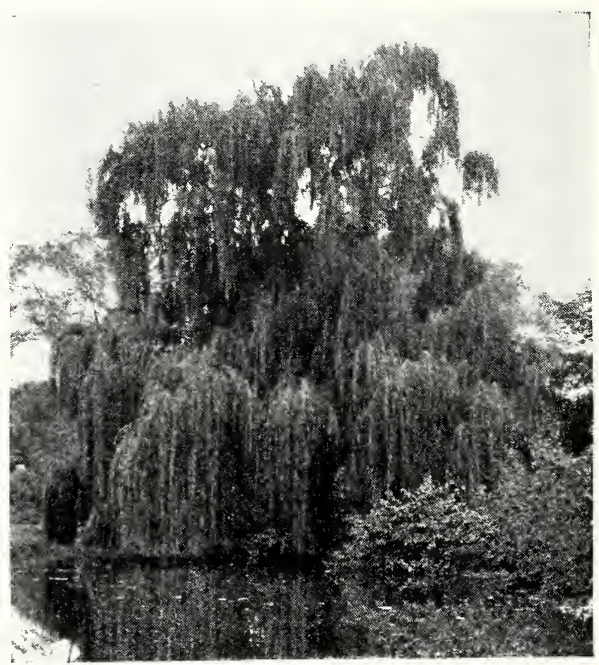

Weeping Willow 


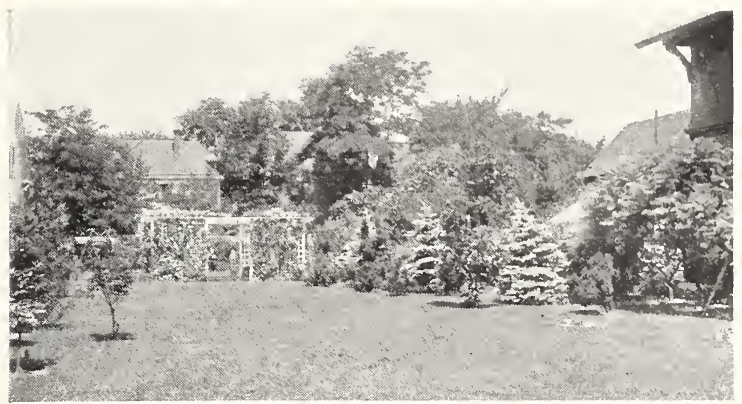

A spot of rare beauty-a real Outdoor Living Room. What a gorgeous contrast-a Climbing Rose (red or pink), Evergreen and Shade Trees

\section{EVERGREEN TREES}

Transplanting may be done in the spring, or in the late summer or early fall.

Ten trees of one size and one variety for nine times the price of one tree. Five trees for one-half this amount.

Arborvitae, American. A shapely lawn tree, unequalled for hedges, shelters, or sereens. $18-24$ in., $\$ 1.00 ; 2 \mathrm{ft}$. . $\$ 2.00 ; 3$ ft., $\$ 3.00 ; 4$ ft., $\$ 5.00 ; 5$ ft., $\$ 7.00 ; 6 \mathrm{ft}$. $\$ \$ .50 ; 7 \mathrm{ft} ., \$ 10.00$.

Arborvitae, Golden (Vervaene). A very pretty slow-growing tree which attains a height of about $10 \mathrm{ft} .15-2 t$ in., $\$ 2.00$.

Arborvitae, Giant. Rich green foliage, with light tips. Very hardy. 12 in., $\$ 2.00$.

Arborvitae, Globe. Small round decorative trees. $9 \mathrm{~m}$., $\$ 1.25 ; 12$ in., $\$ 2.00 ; 15$ in., $\$ 2.50 ; 18$ in., $\$ 2.75$.

Arborvitae, Hovey's. Globe-shape. Slow-growing, very pretty. 18 in., $\$ 2.00 ; 2$ ft., $\$ 3.00$.

Arbrovitae, Parsons (T. OC. compacta). Very attractive deuse little trees which are very useful when a lowgrowing variety is wanted. $12-15$ in., $\$ 1.25$.

Arborvitae, Pyramidal. Slender, formal-shaped trees of pretty dark green. 18 in., $\$ 2.00 ; 2 \mathrm{ft} ., \$ 2.50 ; 21 / 2 \mathrm{ft}$. $\$ 3.25$ : $3 \mathrm{ft} ., \$ 4.00 ; 31 \%$ ft., $\$ 5.00 ; 4 \mathrm{ft} ., \$ 6.50$.

Arborvitae. Rosenthal's. A compact dark green tree. Grows about $\mathrm{S}$ ft. tall. Slow grower. 2-3 ft., $\$ 4.00$.

Arborvitae, Siberian. A harly compact variety which grows $10-15 \mathrm{ft}$. tall and is excellent for hedges and screens. 12 in., $\$ 2.00 ; 18$ in., $\$ 2.50 ; 2$ ft., $\$ 3.00$.

Fir, Balsam. Forms regular pyramid shape and has sweet scente 1 rark areen foliage. 12 in.. $75 \mathrm{c} ; 18$ in., $\$ 1.00$; $2 \mathrm{ft} ., \$ 1.50 ; 30$ in., $\$ 2.00 ; 3 \mathrm{ft} ., \$ 2.50$.

Fir, Silver. Very pretty, bluish tree. Retains its beauty for years. 12 in., $\$ 2.00 ; 1 S$ in.. $\$ 3.50$.

Hemlock. Especially beautiful when laden with snow. Ised as a lawn tree or in hedges. Grows in sunlight or shade. 12 in., $\$ 1.50 ; 18$ in., $\$ 2.00 ; 24$ in., $\$ 3.00$; 30 in., $\$ 4.00 ; 30$ in., $\$ 5.00 ; 4 \mathrm{ft} ., \$ 6.50$.

Juniper, Pfitzer's. Horizontally spreading, feathery. graygreen. Dwarfish. $12 \mathrm{in..} \$ 2.50 ; 15 \mathrm{in.}, \$ 3.00 ; 1 \mathrm{~s}$ in. $\$ 3.50 ; 24$ in. $\$ 4.50 ; 30$ in $\$ 5.50$.

Juniper. Plumed Spreading (Depressa plumosa). An improved plumed form of the common spreading Juniper. $12-15$ in., $\$ 1.00$.

Juniper, Polish. Hardy, upright. 18-24 in., \$2.50; $2 \mathrm{ft}$. $\$ 3.50$.

Junip?r. Sabina. Savin Juniper. Semi-rlwarf. Tase-shape. Dark green foliage. $12 \mathrm{in.,} \$ 2.00: 15 \mathrm{in.}, \$ 2.75: 1 \mathrm{~s}$ in. $\$ 3.50 ; 24$ in.. $\$ 4.50 ; 30$ in., $\$ 6.00$.

Juniper. Spiny Greek. (J. exce'sa stricta). Stylish, dwarfgrowing trees. Blue-gray. Pointel. 15-18 in., \$2.5f)

Juniper. Swedish. Column-shape with gray-green foliage. $12-15$ in., $\$ 1.50 ; 15-1$ s in.. $\$ 2.00$. 
Juniper, Waukegan. A spreading, low-growing variety whose soft blue to purple color contrasts prettily with other evergreens. 12 in., $\$ 3.00$.

Larch. See Urmamental Shade Trees.

Pine, Austrian. Has long dark needles, and thrives near the seashore. 18 in., $\$ 2.00 ; 24$ in., $\$ 3.00 ; 30$ in., $\$ 4.00$; $3 \mathrm{ft} ., \$ 5.00 ; 4 \mathrm{ft} ., \$ 6.00$.

Pine, Mugho. Low, bushy, pretty tree which is very useful in foundation planting, front of evergreens, or on hillsides. $12-15$ in. spread, $\$ 2.50 ; 15-15$ in., $\$ 3.00$.

Pine, Norway. A native dark green variety with long needles. $2 \mathrm{ft} ., \$ 1.50 ; 3 \mathrm{ft} ., \$ 3.00 ; 4 \mathrm{ft} ., \$ 4.00$.

Pine, scotch. Has long, bluish-green needles and makes good shelter planting. $2 \mathrm{ft}$., $\$ 2.00$; $30 \mathrm{in.,} \$ 2.50$; $3 \mathrm{ft}$, $\$ 3.00 ; 4$ ft., $\$ 5.00$.

Pine, White. Native variety which is excellent for trimmed hedges, shelter, or windbreak. 15 in., $\$ 1.00 ; 2 \mathrm{ft}$, $\$ 1.50 ; 3 \mathrm{ft} ., \$ 2.50 ; 4 \mathrm{ft} ., \$ 3.50$.

Red Cedar. A beautiful, slender, upright dark green, native tree. $2 \mathrm{ft} ., \$ 2.50 ; 3 \mathrm{ft} ., \$ 3.50 ; 4 \mathrm{ft} ., \$ 5.00$.

Retinospora filifera. Thread-like Cypress. A very graceful small tree with deep green drooping foliage. 12-18 in., $\$ 1.50$; $18-24$ in., $\$ 2.00 ; 2-3$ ft., $\$ 3.00$.

Retinspora filifera aurea. Golden Thread-like Cypress. A very pretty bright golden form. $12-18$ in., $\$ 1.50 ; 18-24$ in., $\$ 2.00 ; 2-3$ ft., $\$ 3.00$.

Retinospora pisifera aurea. Golden Sawara Cypress. Very hardy, gracefully drooping variety with good color. $12-15$ in., $\$ 1.50 ; 15-18$ in., $\$ 2.00$.

Retinospora, plumosa aurea. Golden Plume Cypress. Feathery, fine-cut foliage. $12-18$ in., $\$ 1.50$; $15-24$ ill., $\$ 2.00$.

Retinospora, squarosa. Moss Cypress. Feathery, bluegreen foliage. $12-18$ in., $\$ 1.50 ; 18-24$ in., $\$ 2.00$.

Spruce, Colorado Blue. Popular steel-blue trees. $1 \mathrm{ft}$, $\$ 4,00 ; 11 / 2$ ft., $\$ 5.00 ; 2 \mathrm{ft} ., \$ 7.00 ; 21 / 2 \mathrm{ft} ., \$ 10 ; 3 \mathrm{ft} ., \$ 12$.

spruce. Colorado Green. Very hardy, useful, and pretty. $1 \mathrm{ft} ., \$ 2.00 ; 11 / 2 \mathrm{ft} ., \$ 3.00 ; 2 \mathrm{ft} ., \$ 4.00 ; 21 / 2 \mathrm{ft} ., \$ 5.00$; 3 ft.. $\$ 6.00$.

Spruce, Koster Blue. The blueist of the blues. 15-18 in., $\$ 6.00$.

Spruce, Norway. A rapid and tall grower. $1 \mathrm{ft.}, \$ 1.00$; 2 ft., $\$ 2.00 ; 3 \mathrm{ft} ., \$ 4.00 ; 4 \mathrm{ft} ., \$ 5.00$.

spruce, White. Very tall-growing tree which is excellent for specimens, hedges, or windbreaks. 18 in., $\$ 1.50$; 2 ft., $\$ 2.00 ; 3$ ft., $\$ 3.00 ; 4$ ft., $\$$ t.00.

Taxus Brevifolia. Dwarf Japanese Yew. Very dark, spreading, slow-growing trees. $12-15$ in. spread, $\$ 3.00 ; 15-18$ in.. $\$ 4.00$.

Taxus. Cuspidata Soreading Yew. Semi-upright in form. 12 in.. $\$ 2.25 ; 15$ in., $\$ 3.00 ; 18$ in., $\$ 3.50$.

\section{EVERGREENS}

In addition to the foregoing, we can furnish other sizes, smaller and larger, and other varieties, and we shall be pleased to furnish information upon request.

Think of These When You Think of Trees.

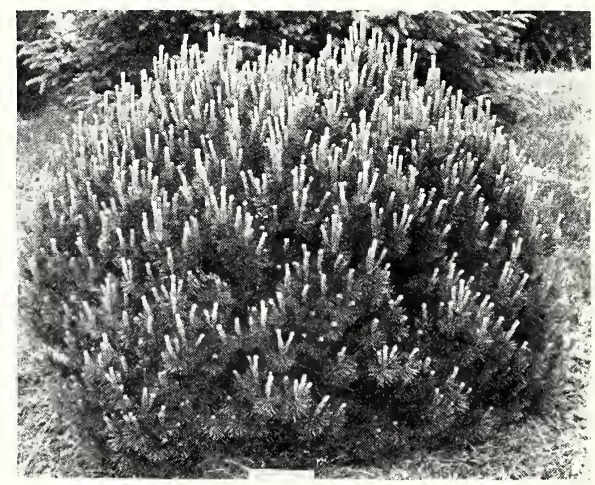

Mugho Pine 


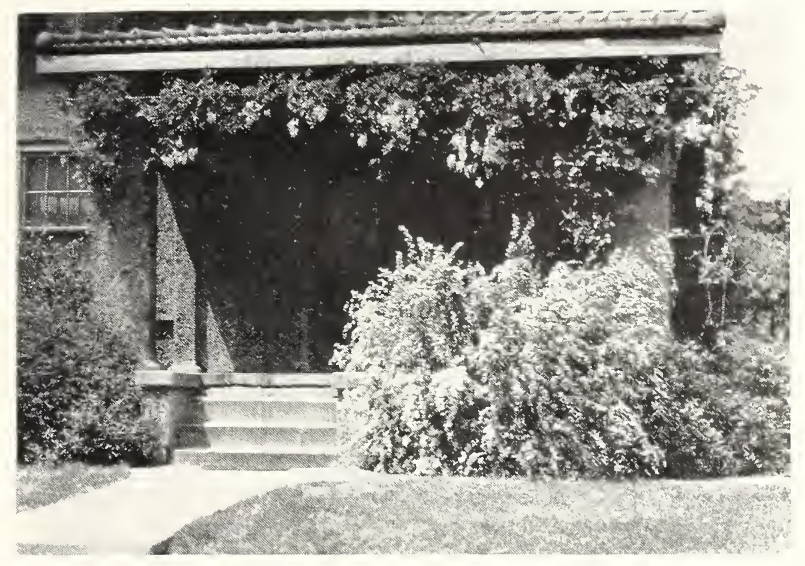

\section{HARDY ORNAMENTAL SHRUBS EVERGREEN AND DECIDUOUS}

Prices quoted are for at least 2-3 ft. shrubs, unless otherwise specified.

Small orders for shrubs can be sent by Parcel Post. Remit 10c additional for each shrub to cover special packing and postage. 5c each. when not less than 3 are ordered.

10 shrubs of one variety for $y$ times the price of one: except as noted; 5 for $1 / 2$ the price of $10 ; 50$ for $1 / 2$ the price of 100 .

Special quotations on quantities.

Almond, Flowering. Old-fashioned shrub, covered in the spring with small, double, rose-like flowers. White and pink $75 \mathrm{c}$.

Althea, Rose-of-Sharon. Flowers in August and September. Erect and tree-like. Double pink or white. 3-4 ft., 75c.

Aralia. Suitable for dry, sandy spots. Has glossy, deep green leaves. Makes a good hedge. 50c.

Azalea, Downy Pinksterbloom. (A. rosea). Abundance of fragrant, beautiful bright rose blossoms about Memorial Day. $12-18$ in., heavy clumps, $\$ 2.00 ; 10$ for $\$ 15.0()$.

Azelea, Flame. Bears a profusion of brilliant orange-colored blossoms in June. $15-18$ in., $\$ 2.00$.

Barberry, Box. A dwarf type used extensively for edging. $12-15$ in., 50c each $\$ 4.00$ for $10 ; \$ 30.00$ for 100 .

Barbery, Japanese. The best shrub for New Englani hedges. Absolutely hardy. Pretty at all seasons. $12-18$ in., 25c each; $\$ 2.00$ for $10 ; \$ 12.00$ for 100 . 18-24 in.. 30c each: $\$ 2.50$ for $10: \$ 18.00$ for 100 . $2-3 \mathrm{ft} ., 50 \mathrm{c}$ each; $\$ 3.50$ for $10 ; \$ 30.00$ for 100 .

Barbery, Red-Leaf. New form of the Japanese variety, with leaves which are always reddish. 12-15 in., 50c: $\$ 4.50$ for $10 ; \$ 40.00$ for 100 .

Beauty Bush, (Kolkwitzia). This recent introduction is a veritable cloud of pink, covered as it is each spring with a profusion of tubular flowers. Grows (i-? ft. tall. $2-3 \mathrm{ft} ., \$ 1.50$.

Bridal Wreath. See Spirea.

Burning Bush. See Euonymous.

Butterfly Bush, or Summer Lilac. A free-growing shrub with fragrant, lilac-like flowers all summer. 50c.

Cinquefoil, Shrubby. Grows $3 \mathrm{ft}$. high. Single yellow flowers all summer. $50 \mathrm{c}$.

Coral Berry. A graceful small shrub suitable for dry spots. Small pink flowers followed by clusters of coral recl berries. $50 \mathrm{c} ; 3$ for $\$ 1.25$.

Cotoneaster, Rock (C. horizontalis). Suitable for rock gardens especially. Very dwarf and spreading. 18-24 in.. $\$ 2.00$. 
Daphne or Garland Flower. A low-growing evergreen shrub with clusters of fragrant pink flowers in early spring and again in the summer and fall. $\$-10$ in., $\$ 1.00$; $10-12$ in., $\$ 1.25 ; 12-15$ in., $\$ 1.75$.

Deutzia, Pride of Rochester. Pink and white flowers in early spring, on upright spikes. 50c.

Deutzia, Dwarf. (Gracilis). A rery useful low-growing shrub with clusters of sweet, white flowers in May and June. 18-24 in., 75c.

Deutzia, Lemoine's. A very pretty shrub growing 3-4 feet tall. Covered with white blossoms in June. 24 in., 60c.

Dogwood, Red-Barked. Beautiful bright red bark. Is especially ornamental in winter. $2-3 \mathrm{ft} ., 40 \mathrm{c} ; 4 \mathrm{ft} ., 60 \mathrm{c}$.

Dogwood, Golden-Barked. Pretty planted with the red. $50 \mathrm{c}$.

Elder, Golden. Large, bright yellow foliage. Showy clusters of white flowers. Good for planting with other shrubs. 50c.

Euonymous or Burning Bush. So-called on account of its autumn color. Corky bark. Ornamental scarlet berries. Grows well in shady or dry spots and makes very pretty shrub. $\$ 1.00$.

Euonymous (Radicaus Vegetus) or Evergreen Bittersweet. A very good ground cover in sunlight or shade. (See vines). 50c. Extra size, 75c. (Not sold by height).

Euonymous Colorata. Similar to preceding. Foliage turns bronze red in the fall. 4 yr. 18 in., $75 \mathrm{c}$.

Euonymous, variegated. Green and white leaves. Extra size, $75 \mathrm{c}$.

Forsythia, Golden Bell. The shrub with beautiful yellow blossoms which appear in April, before the leaves come out. 50c. Weeping variety, 50c.

High Bush Cranberry. Flat heads of white flowers in MayJune, followed in July by scarlet berries. $75 \mathrm{c}$.

Honeysuckle, Morrowi. White flowers followed by bright red berries. Spreading in form. 50c.

Honeysuckle, Tartarian. Upright grower with red flowers followed by bright red fruit. 50c.

Hugonis Rose. A beautiful shrub-like rose which is covered with fragrant yellow flowers in May. Has good foliage and is attractive as a lawn specimen. $\$ 1.00$.

Hydrangea, Everblooming, or Hills-of-Snow. Begins to produce white heads of flowers in June and continues until fall. $18-24$ in., $50 \mathrm{c} ; 2-3 \mathrm{ft} ., 60 \mathrm{c} ; 3-4 \mathrm{ft} ., 75 \mathrm{c}$.

\begin{tabular}{|c|c|c|}
\hline Each & $5-25$ & $25-100$ \\
\hline $3-24$ in. $50 \mathrm{c}$ & 45c each & $40 \mathrm{c}$ each \\
\hline 3 ft. $60 \mathrm{c}$ & $55 \mathrm{c}$ each & $50 c$ each \\
\hline ft. $75 \mathrm{c}$ & 70c each & $60 \mathrm{c}$ \\
\hline
\end{tabular}

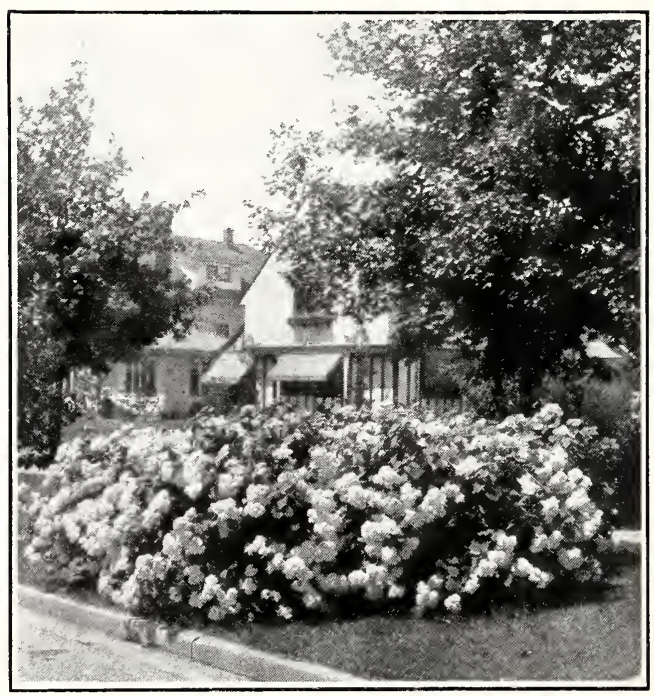

Hydrangea Hills-of-Snow 
Hydrangea, P. G. One of the showiest and most popular. shrubs. Cone-shaped clusters of white flowers which later turn pink. Very ornamental as single plants, in beds, or in rows. Prices same as Ererblooming Hydrangea.

Hydrangea P. G. Tree Form. Trained ot a single stem or stalk, branching out at the height of about $2-t \mathrm{ft}$., $\$ 1.25 ; 4-5 \mathrm{ft} ., \$ 1.50$.

Japanese Quince. Fire Bush. Searlet flowers in May, 2-3 $\mathrm{ft}$., $75 \mathrm{c} ; 3-4 \mathrm{ft} ., \$ 1.00$.

Kerria, Single and Double. Globe Flower. Bright green branches with yellow flowers. $75 \mathrm{c}$.

Kerria, White. Syringa-like flowers in May. 75.c.

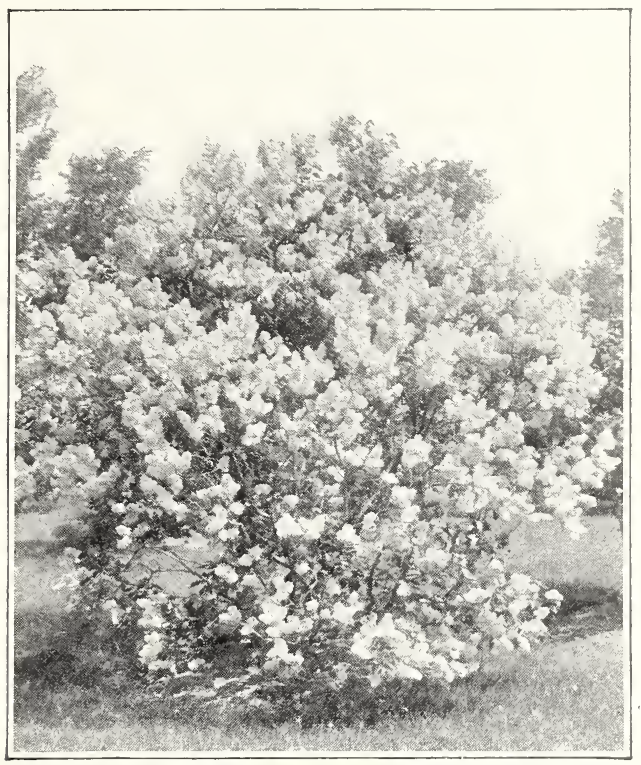

Lilac-White

Lilac, Purple. State flower of New Hampshire. One of the good, old New England shrubs. $2-3 \mathrm{ft} ., 50 \mathrm{c}$; 5 for $\$ 2.25$. $3-4 \mathrm{ft} ., 75 \mathrm{c}$.

Lilac, White. Similar to above. 2-3 ft., $75 \mathrm{c}$.

\section{NAMED VARIETIES OF LILACS}

Very handsome shrubs, and a noteworthy addition to our assortment.

Abbreviations_"S," Single; "D," Double.

$2-3 \mathrm{ft} ., \$ 1.00 ; 3-4 \mathrm{ft} ., \$ 1.50$.

Belle de Nancy. D. Rose with white center.

Charles X. S. Reddish purple. Vigorous.

Congo. S. Deep reddish purple.

Marie Le Graye. S. Pure white. Fragrant.

Michael Buchner. D. Pale lilac. Very dbl. Dwarf.

Mme. Cassimer Perier. D. Creamy white. Late.

Pres. Grevy. D. Large blue flowers.

Ludwig Spaeth. S. Dark red. Large clusters.

Lilac, Persian. Purple. Slender, drooping, graceful. \$1.00.

Lilac, Persian. White. Grows 6-8 ft. tall. \$1.00.

Lilac, Rothamagensis. Free-flowering, fragrant, slender and arching. Grows 6-8 ft. tall. \$1.00. 
Mountain Laurel. Broad-leaf evergreen shrub with great clusters of pink and white blossoms in June, 15-1S in. clumps, $\$ 2.00 ; 18-24$ in. clumps, $\$ 3.00 ; 2-3$ ft. clumps, $\$ 4.00$ ( 10 of one size for 9 times the price of one).

Pacysandra or Japanese Spurge. A low-growing and spreading broad leaf evergreen, 6-10 in. high, very useful as a ground cover in shady spots in place of grass, or in sunlight. $25 \mathrm{c} ; \$ 2.00$ for 10 . Should be planted not less than 4 to the square foot.

Plum, Purple leaf. See trees.

Privet. Amoor River. Grows up-right like the California. but is hardy. 12-18 in., 15c; $\$ 12.00$ per $100 ; 18-24$ in., $20 \mathrm{c} ; \$ 15.00$ per 100 .

Privet. California. Upright grower with dark green leaves. Liable to winter kill in exposed places. 2-3 $\mathrm{ft}$., $20 \mathrm{c}$ each 10 for $\$ 1.50 ; \$ 10.00$ for 100 .

Privet, Chinese (Ibota). A very hardy type, better adapted to northern New England than the California variety which it resembles. Makes an excellent hedge, 18-24 in.. 25c each; $\$ 2.00$ for $10 ; \$ 15$ for 100 . $2-3 \mathrm{ft} ., 35 \mathrm{c}$ each ; $\$ 2.50$ for $10 ; \$ 18.00$ for 100 , 3-4 ft., $50 \mathrm{c}$ each ; $\$ 3.00$ for $10 ; \$ 24.00$ per 100 .

Privet Ibolium. A cross between Ibota and California. Has the hardiness of the former and the appearance of the latter. $2-3 \mathrm{ft} ., 25 \mathrm{c} ; \$ 2.00$ for $10 ; \$ 15.00$ per 100 . $3-4$ ft. 50c each; $\$ 3.00$ for $10 ; \$ 20.00$ for 100 .

Rhodendron, (Catawbiense). Hardiest and best all-around variety. Large trusses of rose-pink flowers. Dark, shiney green leaves. $1 \mathrm{ft}$. clumps, $\$ 2.00 ; 1 \mathrm{~s}$ in. clumps, $\$ 3.00 ; 2 \mathrm{ft}$. clumps, $\$ 4.00$.

Shadblow, Downy (Amelanchier canadensis). Early flowering native shrub. whose white blossoms are followed by ornamental, edible, red fruits. $2-3 \mathrm{ft}$. clumps, $75 \mathrm{c}$.

Smoke Bush. Much admired for its curious hair-like flowers which cover the whole plants and give the appearance of smoke in late summer. $\$ 1.00$.

Snowball. Japanese. A beautiful strong-growing shrub with clusters of white flowers in June. $75 \mathrm{c}$.

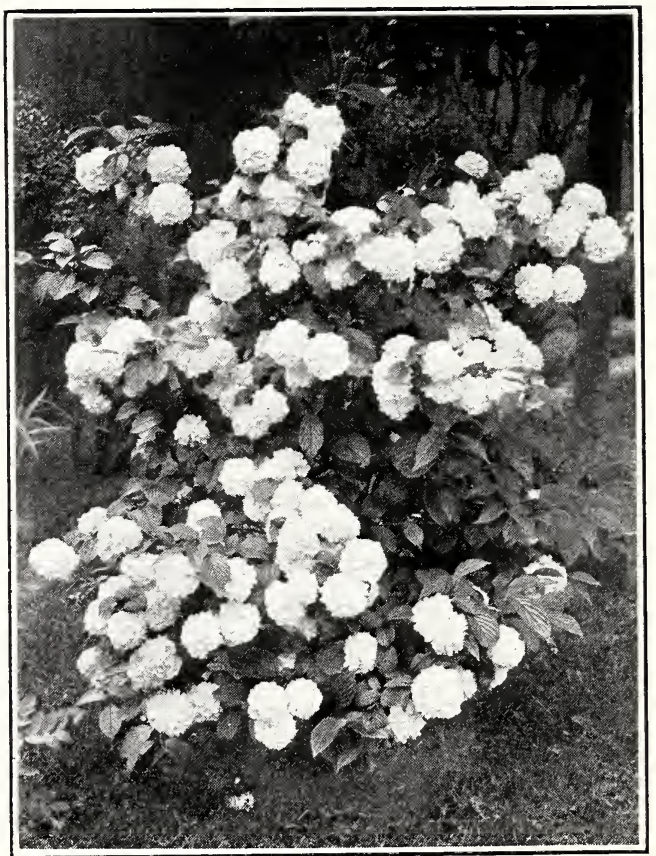

Japanese Snowball 


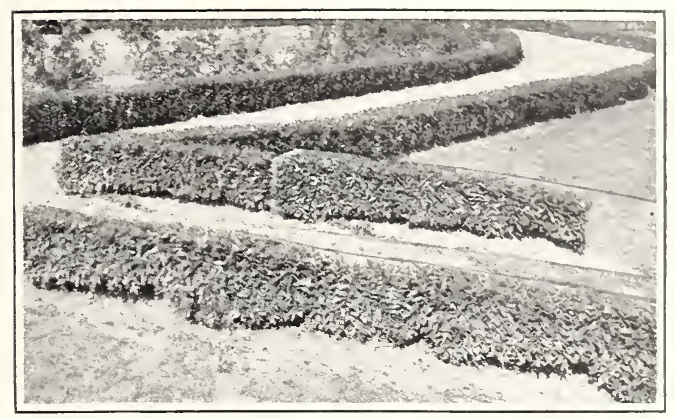

Privet

Snowberry. Small pink flowers in summer, followed by waxy marble-like berries in fall. $50 \mathrm{c} ; 3$ for $\$ 1.25$.

Spirea. Anthony Waterer. The brightest color of all spireas. Pink flowers from June to fall. Low-growing. 1S-24 in., 50c.

Spirea. Billardi. Flower spikes of bright pink. Grows $\overline{-}-6$ ft. tall. Good for dry places. 50c.

Spirea, Bridal Wreath (Van Houttei). Surpasses all other spireas in beauty and grace. Fine foliage and slender arching branches covered with pure white flowers in Iay. Fine as a single specimen or planted in clumps, and makes a beautiful hedge. Each
$5-25$
$40 \mathrm{c}$ each
$50 \mathrm{c}$ each
$25-100$
$35 \mathrm{c}$ each
$40 \mathrm{c}$ each

$2-3$ ft. $50 \mathrm{c}$

$3-4 \mathrm{ft} .60 \mathrm{c}$

Spirea. Froebeli. Flowers bright crimson. Foliage turns red in autumn. Similar to Anthony Waterer but grows taller. $50 \mathrm{c}$.

Spirea, Golden (Ninebark). One of the best golden leaved shrubs. Vigorous grower which attains a height of $\mathrm{S}$. $10 \mathrm{ft}$. Spreading and drooping branches with $3 \mathrm{in}$. clusters of white flowers. 50c.

Spirea, Korean. (S. Trichocarpa). Forms dome-shaped bush 4-6 ft. tall and is covered in June with large round clusters of snowy flowers. A new shrub which will be very popular. $2-3 \mathrm{ft}$. $\$ 1.00$.

Spirea Prunifolia. The true Bridal Wreath. Round, shining leaves, which assume beautiful autumn color. Many white flowers in May. 60c.

Spirea. Thunbergi. Has flowers in long. close clusters in April and Hay and retains its fine delicate foliage until late fall, changing to a beautiful color. $50 \mathrm{c}$.

Sumac. Very ornamental shrubs suitable for massing in corners or the like. Red foliage and fruit. $3-4 \mathrm{ft} ., 50 \mathrm{c}$; $4-6 \mathrm{ft} ., 75 \mathrm{c}$.

Summersweet (Clethra). Racemes of creamy white flowers with spicy fragrance. July to September. 18-24 in., clumps, 50c.

Syringa, Golden. A compact-growing shrub with beautiful yellow foliage in the spring. Makes a pleasant contrast with other shrubs. 18-24 in., $75 \mathrm{c}$.

Syringa, Avalanche. Graceful arching shrub with snowy white flowers. $50 \mathrm{c}$.

Syringa. Large-Flowered. Vigorous grower. 2-3 ft., 50c. 3 for $\$ 1.25$. $3-4 \mathrm{ft} ., 75 \mathrm{c} ; 3$ for $\$ 2.00$.

Syringa, Lemoine's. Slender, arching branches, covered in IIay with small, double white flowers. $50 \mathrm{c}$.

Syringa, Virginalis. Tery large, semi-donble fragrant flowers. Beautiful and much admired. $75 \mathrm{c}$.

Syringa, White or Mock Orange. Creamy white, orangescented flowers in May and June. $50 \mathrm{c}$.

Virburnum. Mayflower. (Carlesi). A new rariety with clusters of early, pink flowers which have Ma,f-flowel fragrance. $18-24 \mathrm{in..} \$ 2.25$.

Weigelia Rosea. For several weeks in early summer covered with pink trumpet-like flowers. 50c. 


\section{HARDY ORNAMENTAL VINES}

Useful for trellises, screening porches, covering fences, piles of rock, and the like.

10 vines of one variety for 9 times the price of one.

$\overline{5}$ for one-half the price of ten.

Vine can be sent by Parcel Post. Add 5c each.

Bittersweet or Roxbury Waxwork. Good for covering trelliswork, trees, walls, etc. Orange flowers and showy crimson fruit. 50c.

Clematis Paniculata or Virgin's Bower. One of the best porch vines; rapid grower, quickly covering trellises with its handsome bright green foliage and profusion of star-shaped, white, sweet-scented blossoms. $50 \mathrm{c}$.

Clematis Jackmani. The best purple clematis. Rapid climber. Very pretty. July to September. $\$ 1.00$.

Dutchman's Pipe. Rampant grower. Large leaves and curious pipe-shaped flowers. Does well in sun or shade. Give it rich, moist soil for best results. $\$ 1.00$.

Euonymous Radicans Vegetus, or Evergreen Bittersweet. A spreading, shrubby vine, useful on low trellises, rocks, walls, or the like and a very good ground cover, growing well in sunlight or shade. 50c. Variegated form, same price.

Euonymous Colorata. Similar to preceding. Foliage turns bronze red in the Fall. 3 yr. 12-18 in. 50c.

Honeysuckle, Hall's Japan. A strong grower with whiteyellow flowers in August. Suitable for covering trellises, banks and the like. $50 \mathrm{c}$.

Honeysuckle, Scarlet Trumpet. Covered with scarlet trumpet-shaped flowers from June to September. 50c.

Ivy, Boston. A popular vine for public buildings of brick or stone. $50 \mathrm{c}$.

Ivy, Engelman's, or Clinging Woodbine. Finely divided leaves and strong tendril discs enabling it to cling to any surface, like Boston Ivy. A good wall covering. Should be used extensively. Hardy. 50c.

Lace Vine. (Polygonum Auberti). Truly a beautiful vine, with its clouds of erect sprays of lacy flowers. $\$ 1.00$.

Matrimony Vine. A hardy, rapid grower which is covered with brilliant crimson berries in autumn. $50 \mathrm{c}$.

Trumpet Vine. A good climber with clusters of trumpetshaped flowers. $50 \mathrm{c}$.

Wisteria, Blue. Rapid growing, woody climber with drooping clusters that should be used extensively. 75c.

Wisteria, White. A rare variety of above; similar except the flowers are pure white. 75c.

Woodbine or Virginia Creeper. Sometimes called American Ivy. Well-known rapid growing climber. Foliage large, deep green, taking on vivid color in the fall. $50 \mathrm{c}$.

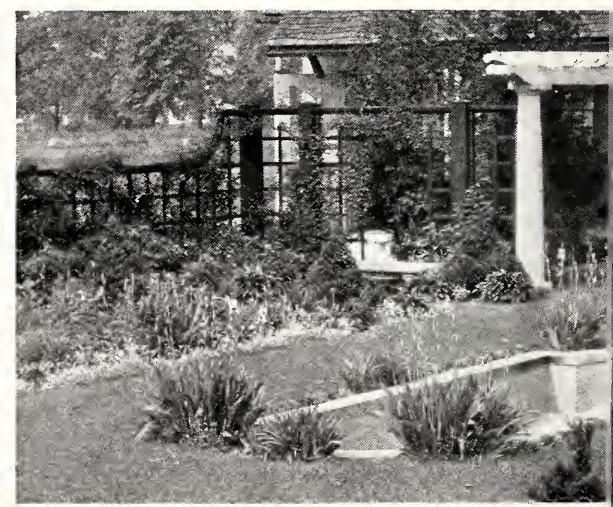




\section{ROSES}

For a number of years, we have been offering mainly Hybrid Perpetual roses, on account of their greater hardiness. Because of their shorter blooming period, however, we are removing some of these from our list and offering more Hybrid Teas. While the latter are not quite as hardy, we feel that as they bloom over such a longer period each summer they are worth running what little additional risk there is of winter injury. If our customers will take a little more care in protecting the bushes each fall by mounding the soil at least a foot high around each plant and putting on manure, straw, or evergreen boughs as extra protection, we feel sure they will get much more satisfaction. The bushes we offer below are strictly No. 1, 2 yr. plants which have been grown in the field, thus insuring vigor and maximum hardiness.

\section{HYBRID TEAS} noted.

Price 75c each. Any 5 or more 60e each. Except as bush.

Rose bushes can be sent by Parcel Post. Add 5c per

Gruss an Teplitz. A fragrant, scarlet, free-growing rose, which is in bloom nearly all summer.

Hadley. Velvety-crimson blooms. Very good for cutting.

Harrison Yellow. Old fashioned bright yellow. Shrubby grower. Do not prune, except to remove dead canes.

J. L. Mock. Brilliant pink. Very double.

Kaiserin Auguste Victoria. Most popular white Hybrid Tea. Very double and very fragrant.

Lady Hillingdon. Blooms continuously. Beautiful apricotyellow. Probably the hardiest Tea rose.

Mme. Butterfly. Bright light pink, shaded with gold. A steady bloomer, particularly in the fall. Quite hardy.

Mme. Caroline Testout. Large, bright rose-pink. Very fragrant and one of the hardiest.

Ophelia. Long-pointed pearl-pink and gold buds. Pearlywhite blooms which are produced in profusion.

Radiance, Pink. Produces abundance of brilliant rose-pink blooms of great fragrance and excellent form. Very popular and quite hardy.

Radiance, Red. Same good habits, blooming qualities, healthy foliage, and dilghtful fragrance as Pink Radiance, but brilliant cerise-red.

Souvenir de Claudius Pernet. Striking sun-flower yellow with large, glossy foliage. Quite hardy.

Talisman. A truly beautiful combination of brilliant orangered buds and glowing yellow and copper shades in the blooms suffused with copper-red and orange rose shades. Especially good in spring and fall and surprisingly hardy. \$1.25 each. 3 for $\$ 3.50$. $\$ 10.00$ per 10 .

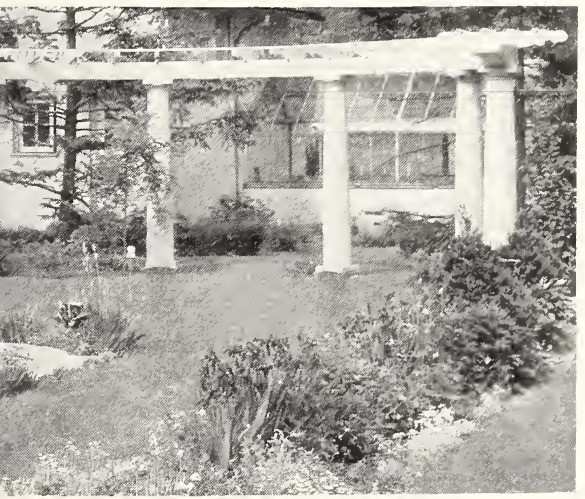




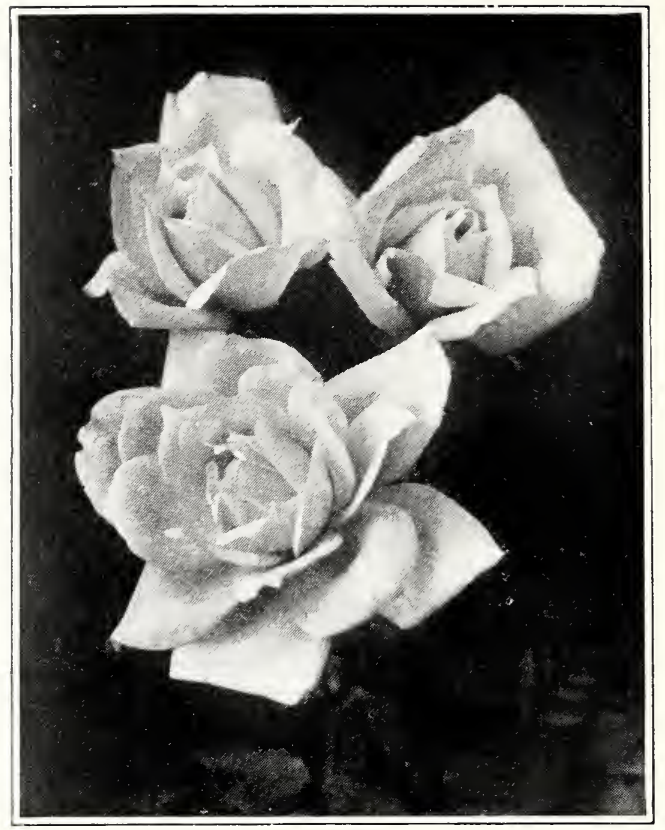

Paul Neyron-(H. P.)

\section{HYBRID PERPETUAL ROSES}

The leading variety in each color. 2 yr. No. 1 Field grown plants. Prices same as Hybrid Teas.

Frau Karl Druschki or White American Beauty. The very best white. A great bloomer, fine for cutting and will grow anywhere.

General Jacqueminot. Bright crimson. Known as the Jack Rose. Rich velvety, a truly wonderful variety. Like Frau Karl Druschki, needs careful pruning and thinning.

Mrs. John Laing. Soft pink. One of the very best liardy roses that was ever grown. A great bloomer.

Paul Neyron. Bright pink. A hardy, healthy variety which generally blooms again in the fall. Almost thornless. Produces very large flowers.

\section{HARDY RUGOSA ROSES}

A hardy type which has a long blooming season, followed by the ornamental large red fruits. Curiously wrinkled foliage. Very spiny. Will grow almost anywhere.

F. J. Grootendorst. Bright red clusters of flowers, which are produced throughout the season. Ideal for hedges or massed planting. 2 yr. No. $1,75 \mathrm{c}$ each; $\$ 6.50$ per 10 .

Hansa. Dark purple red. Especially hardy. 2 yr. No. 1. $75 \mathrm{c}$ each ; $\$ 6.50$ per 10.

Sir Thomas Lipton. Produces large, double, white blooms all season. 2 yr. No. 1 , 75c each; $\$ 6.50$ per 10 ).

Rosa Rugosa White. Many large single blooms.

Rosa Rugosa Red. Identical with white, except in color. 2 vr. No. 1, 60c each; $\$ 5.50$ per 10.

\section{A NEW YELLOW ROSE}

Hugonis Rose. Golden Rose of China. The best single flowered rose and one of the best shrubs for general gardem use. Fragrant yellow flowers $2 \frac{1}{2}$ in. across, forming continuous bands of color on long gracefully arching canes. Blooms very early and is perfectly hardy. 2 yr. plants, $\$ 1.00 ; \$ 9.00$ per 10 .

Choice 2 yr. bushes, 75c each; 5 or more, $60 \mathrm{c}$ each. Roses can be sent by Parcel Post. Add 5c per bush. 
HARDY CLIMBING OR RAMHIER ROSES

These are very beautiful when planted at various places about houses, garages, and other buildings. Given a suitable trellis or wire on which to climb, they will furnish color and fragrance for many seasons.

2 yr. plants, 50c each, $\$ 4.50$ for any 10 (excent as noted). Add 5́c per bush if to be shipped by I'arcel l'ost.

American Pillar. Great clusters of single pink flowers with a white eye. Vigorous grower.

Climbing American Beauty. An unusually hardy variety, suited for northern exposures in any locality. Beautiful rosy crimson flowers on separate stems, suitable for cutting. Has very good foliage and is a very satisfactory variety. Not a vigorous climber. 60c. By mail, 65c.

Dorothy Perkins. Beautiful, large clusters of clear, shellpink flowers. Thrifty and rapid grower, suitable, like Excelsa, for growing on trellises, pillars, posts, walls, or the like.

Dr. Van Fleet. By vote of the members of the American Rose Society, acclaimed the Best Climbing Rose. Beau. tiful big clusters of pink flowers. Vigorous grower. Glossy, healthy, dark green foliage. $60 \mathrm{c}$.

Excelsa. The very best double red rambler. A decidec? improvement on Crimson Rambler, bearing fully as many flowers and retaining its foliage in a inuch healthier condition. Produces an abundance of large. double flowers. Vigorous grower.

Gardenia. Covered with rich yellow buds which open to creamy white. Vigorous grower with excellent foliage.

Mary Wallace. Vigorous, rapid grower. Long-stemmed pink blossoms, good for cutting. 60c. By mail, 65̄c.

Paul's Scarlet Climber. The most virid of all the climbers. This is a new variety and it is fast becoming the most popular on account of its wonderfully brilliant color. Has good, healthy foliage, is a vigorous grower, and produces an abundance of scarlet flower clusters. You will make no mistake if you plant this variety. $60 \mathrm{c}$. By mail, 65̃c.

Tausendschon. "Thousand Beauties." Large clusters of medium-sized, creamy white to soft pink flowers.

White Dorothy Perkins. The best white climber, Similar in all respects to the Pink Dorothy Perkins except in color. Equally desirable in every way.

Wichuraiana. A trailing variety which is ahmost evergreen and which makes a good ground-cover. (rlossy leaves and clusters of pure white flowers.

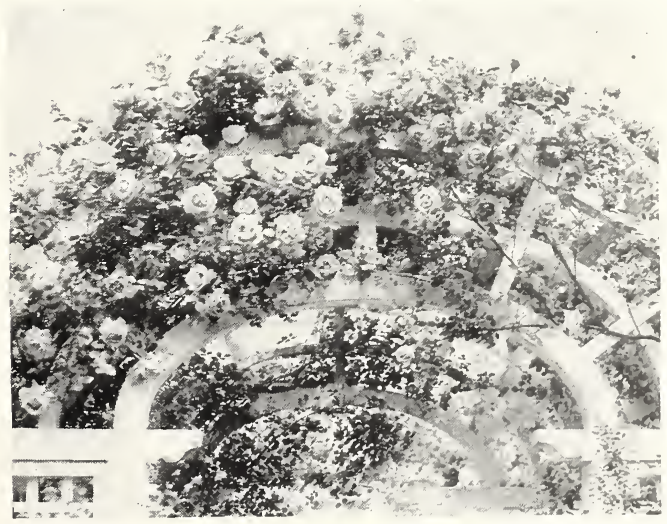

Climbing American Beauty 


\section{POLYANTHA OR BABY ROSES}

A charming class of roses, seldom growing over 15-18 inches high, and producing an abundance of clusters of small, perfectly formed flowers all summer long, until cold weather. Very useful and attractive in beds or borders and fine for cutting. Very hardy.

2 yr. No. 1 bushes, 75c each. Any 5 or more, 60c each. Add 5c per bush if to be shipped by Parcel Post.

Ellen Poulsen. Brilliant rose-pink. Very free flowering. Vigorous grower.

Erna Teschendorff. Bright red. Very popular.

Ideal. High clusters of small dark red flowers.

Jessie. Bright cherry crimson that holds its color well. Flowers are full and borne in large compact trusses that are produced freely through the season.

Katharina Zeimet. Large clusters of small, full, double, white flowers.

La Marne. Bright salmon rose.

Miss Edith Cavell. A profusion of brilliant crimson flowers in great abundance.

Orleans. Bright geranium red. Bushy plants covered with blossoms all season.

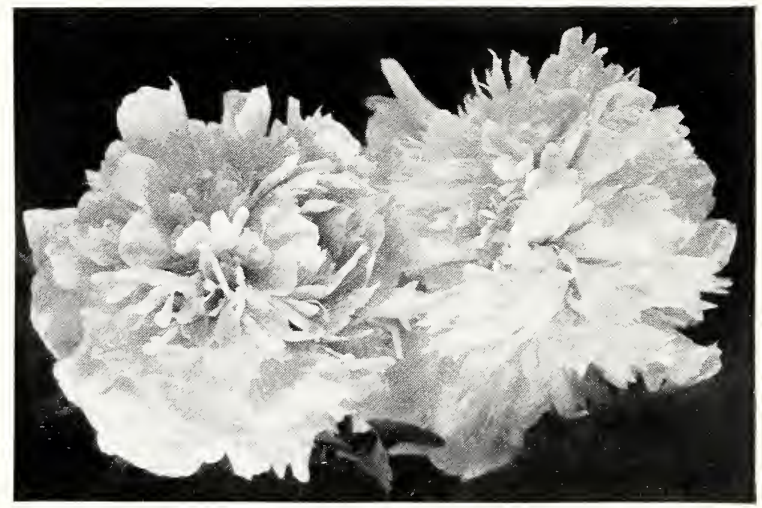

\section{CHOICE PEONIES}

Everybody loves peonies. They are perfectly hardy and require no special care or protection. Use a little lime on the soil before planting, if convenient, to make sure it is sweet. Fertilize with wood ashes and sheep manure in the spring, and with bone meal after flowering, or work 1 pint (1 lb.) of Vigoro around each plant when buds appear. See page 36.

On the basis of ten points as a perfect score, the American Peony Society, rates all our varieties, except one, at over seven points, and most of them over eight points.

September is the best month for transplanting, but plants may also be moved with good results in the spring, if moved early.

Our plants are strong three to five eye divisions.

For Parcel Post add 5c for each root; 4c each when six or more are ordered.

Special Offer-Three plants. one red, one pink, one white (our selection) for $\$ 1.00, \$ 1.10$ by mail.

See Our Special Offer for Bulbs for a Border of Gladiolas

A succession of blooms all Summer and Fall, Page 36 . 


\section{WHITE VARIETIES}

\section{Early}

Duchess de Neymours. Cup-shaped, sulphur white. Tбe.

\section{Mid-Season}

Festiva Maxima. Large ivory white, red splash. $50 \mathrm{c}$.

Solfatere. White-petaled, handsome variety. T5c.

Albatre. Ivory white, and very pretty. $\$ 1.00$.

Madame Crousse. Beautiful, large white flower. \$1.00.

Mlle. Rousseau. Large, full, finely shaped flowers. \$1.50.

\section{Late Mid-Season}

Duc de Wellington. Vigorous, tall. Pyramidal flowers. 50c.

Avalanche. Ivory white, convex flowers, red fleck. $\$ 1.00$.

Baroness Schroeder. One of the best. Iurge white flowers with baby-pink center. Strong grower. Profuse bloomer. $\$ 1.50$.

Solange. Large, waxy white, reddish golden tint. $\$ 3.50$.

\section{Late}

Couronne d'Or. Large pure white, golden stamens. 75c.

Mireille. Largest clear white peony. $75 \mathrm{c}$.

Tourangelle. Fragrant, creamy white with salmon. $\$ 3.00$.

\section{RED VARIETIES} Early

Officinalis Rubra. The old-fashioned early red. T5c.

Mons. Baral. Lilac Rose. 50c.

\section{Late Mid-Season}

Felix Crousse. Large, deep, ruby red. Best red. 75c.

\section{PINIK VARIETIES \\ Early}

Early Pink. The earliest. Good bloomers. 50c; 3 for $\$ 1.00$.

Edulis Superba. Fragrant, rose-pink. 50c.

Iadame Calot. Hydrangea pink. Great bloomer. $\$ 1.00$.

\section{Mid-Season}

Madame Geissler. Very large, well-formed, showy. 75c.

La Tulipe. Light, flesh pink, large and globular. $75 \mathrm{c}$.

Eugenie Verdier. Flesh center, lighter outer petals. $\$ 1.00$.

Gloire de Chas. Gombault. Mauve pink with creamy white collar. $\$ 1.00$.

Venus. Delicate shell pink, flesh color. Very fine. $\$ 1.50$.

\section{Late Mid-Season}

Madame Emile Galle. Very beautiful, shell pink. $\$ 1.00$.

Madame Boulanger. Rose, shading to silvery flesh. Very large and fine. $\$ 1.00$.

Late

Iadame Lebon.' Cherry pink. Large, full blooms. 50c.

Mlle. Leonie Calot. Salmon pink, shading to flesh. Great bloomer. $\$ 1.00$.

Albert Crousse. Large, shell pink, vigorous. \$1.50).

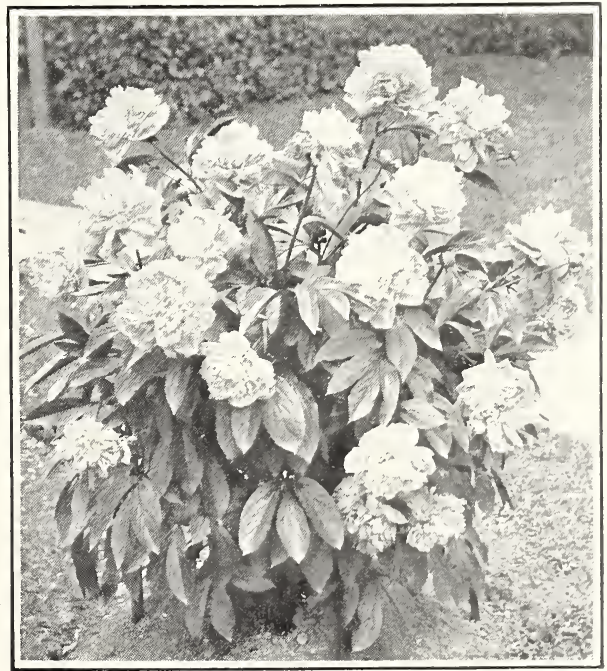




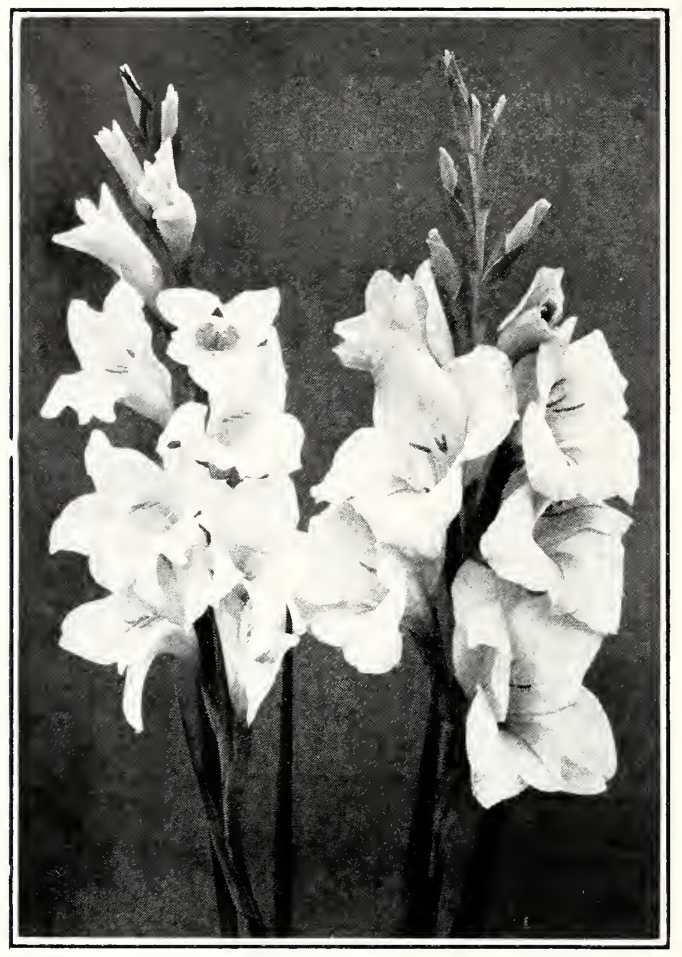

\section{GLADIOLAS}

Any good garden soil will raise good "Glads" if you plant good bulbs. Set the bulbs stem-end up, from three to five inches apart and four to six inches deep, covering them gradually as the tops come up through the soil (as in planting asparagus roots). Deep planting prevents the flowers from falling over and makes staking unnecessary. At least fifty days are required from planting to blooming. For a succession of blooms, do not plant all bulbs at one time.

Experiments at Cornell show that best results are secured with gladiolas when the bulbs are procured not very far away-which is another good reason why you may weil get your bulbs from us, here in the heart of New England.

In cutting blooms use a sharp knife and leave at least two or three leaves on the plant.

When the leaves turn brown in the fall, lift the bulbs. dry them in the sun, and after removing the old shrivelled bulb, store in a cool dry place where they cannot freeze.

The following varieties are some of the most beautiful. They will delight the eye and gladden the heart of any flower-lover.-Please Order Early.

For a ready-mixed assortment, we especially recommend the following:

Exonian Mixture. A good assortment of beautiful varieties. 25 c per doz.; 50 bulbs for $\$ 1.00$; $\$ 1.50$ per 100 .

Good-As-Grow Mixture. A very good selection of varieties. Smaller bulbs than Exonian Mixture, but guaranteed to bloom. 50 bulbs for $50 \mathrm{c} ; 100$ bulbs for $\$ 1.00$.

On all bulb orders amounting to $\$ 1.00$ we pay the postage. Otherwise add 5c for each 12 bulbs.

Six bulbs of one variety for one-half the dozen price.

Small but flowering size. bulbs at $1 / 2$ the price of full-size bulbs. 
A. E. Kunderd. Deep cream and pink. Ruffled. $\$ 1.5 \$ 1.50$

Ah: Pale apricot, pink and yellow: beantiful opening-bud like Ophelia rose. 2 for 25 c. . $10 \quad 1.00$

Alice Tiplady. (Prim.*) Orange saffron. Much

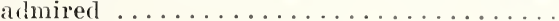

American Beauty. Very large, brilliant flowers

Anna Eberius. Large, deep velvetr purple... .11

Baron Hulot. The best dark blue......... .1.

Butterboy. (Prim.*) Large buttercup yellow. .11

Byron L. Smith. Lavender pink, on white ground. Very beautiful variety........

Chateau Thierry. Bright scarlet rerl........

Clristine M. Kelway. Soft pink, canary-yellow throat. Early, large, tall............

Crimson Glow. Finest scarlet crimson.......

Dexter. (Prim.*) Delicate cream-yellow. B for

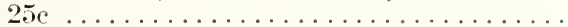

Dorothy McKibbin. Apple blossom pink. Ruffled. Tery early. 3 for $25 \mathrm{c} \ldots \ldots \ldots \ldots . . .11$

Dorothy Wheeler. (Prim.*) Rich, rose-pink. .

Dr. Bemett. Large, beautiful, fiery red......

Dr. Van Fleet. Rosepink. Fxtra early.....

E. J. Shaylor. Reantiful, deep rose-pink. Early Ruffled. 3 for $25 \mathrm{c} . . \ldots \ldots \ldots \ldots \ldots$.

Elizabeth Tabor. Rosy-pink with crimson bloteh.

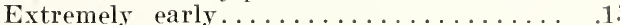

Elora. Burbank's. Early. Cream-white. 3

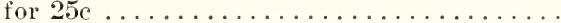

Empress of India. Very dark, velyety-red featherings of American Beauty pink........

Evelyn Kirtland. Rosy-pink. Tall grower....

Fern Kyle. Large, handsome, showy white...

Flora. Large, beautiful canary yellow.......

Giant Myrtle. Extra large. Showy. Soft pink

Giant Nymph. LaFrance pink. Very tall....

Gold. One of the very best yellows..........

Golden Girl. (Prim.*) Deep yellow. Very pretty. 3 for $25 \mathrm{c} \ldots \ldots \ldots \ldots \ldots \ldots \ldots$

Golden Measure. Vigorous. Large, yellow.

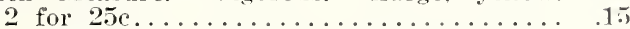

1.00

.101 .00

$.25 \quad 2.50$

.11 1.00

$10 \quad 1.00$

$1.5 \quad 1.50$

$10 \quad .75$

$1.5 \quad 1.50$

$.10 \quad 1.00$

151.50

$10 \quad 1.00$

.151 .50

$.15 \quad 1.50$

.11 1.00

$1.5 \quad .50$

Golden Princess. Deep, clear, golden yellow. .

Gretchen Zang. Beautiful, salmon pink.....

Halley. Showy. Early. Salmon pink. 6 for

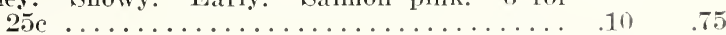

H. C. Goelıl. Large, pinkish white, with crim-

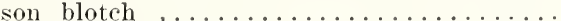

Helen Franklin. Ruffled. White with narrow violet throat markings. 3 for $25 \mathrm{c} . . .$. .

Henry Ford. Striking, smoky dark purple....

Herada, Clear maure. Truly handsome....

Independence. Brilliant begonia pink.......

Jack London. Light salmon. Yellow throat 10

Jenny Lind. Apricot pink. Very dainty. . . . . . 15

Jewell. (Prim.*) Clear, salmon pink.........10

Kunderd Glory. Creamy apricot. light pink

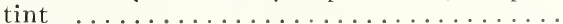

Le Marechal Foch. Beautiful. Farly. Targe. Pink. 4 for $25 \mathrm{c} \ldots \ldots \ldots \ldots \ldots \ldots \ldots$

Lily White. One of the best whites. Farly...

Louise. Bright lavender with wine colorel

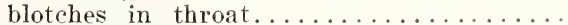

Maiden's Blush. (Prim.*) Long-stemmerl.

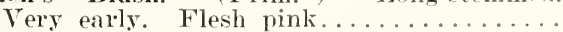

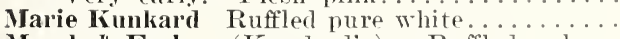

Iarshal Foch. (Kunderd's). Ruffled salmon pink. Tery showy, large flower......... 


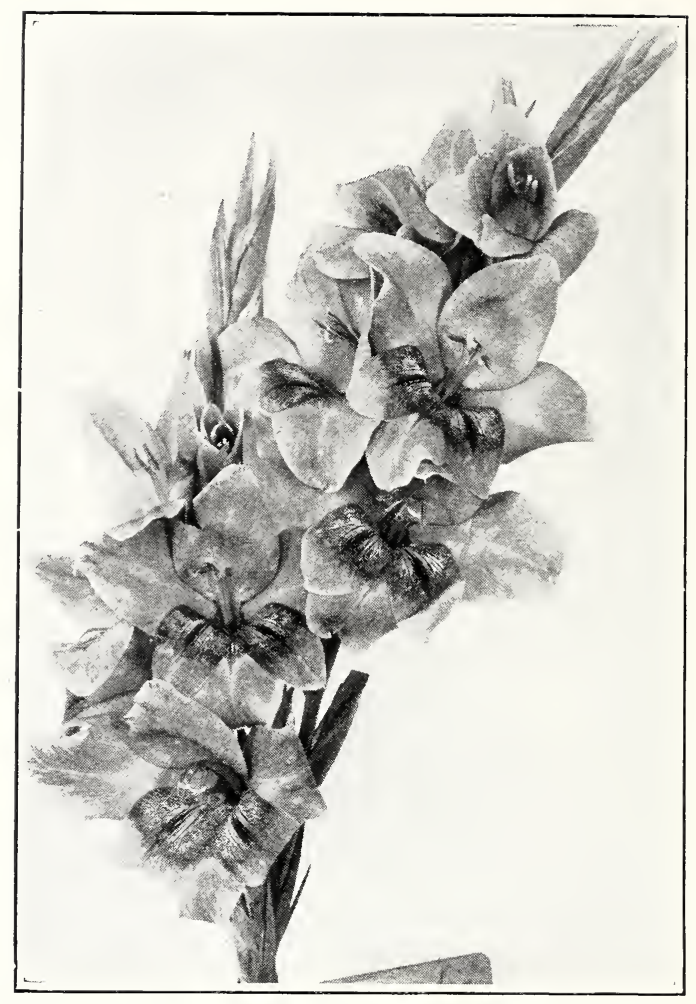

Each Doz.

Mary Fenuell. Deep lilac. Yellow throat....\$ $.10 \$ .75$

Mary Pickford. Delicate creamy white. Throat softest sulphur yellow. Very beautiful....

Ming Toy. (Prim*) Showy, deep buff. Yel-

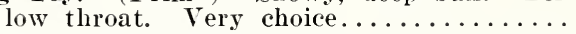

Mrs. Dr. Norton. Beautiful, tall, white. Edges

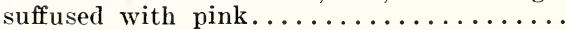

Mrs. F. C. Peters. Amaranth, pink, with purple blotch. Slightly ruffled. Tall.........

Mrs. Francis King. Flaming salmon red.....

Mrs. Frank Pendleton. Light pink. Showy red blotch. Slightly ruffled. Tall..........

Mrs. H. E. Bothin. Geranium pink, scarlet center. Ruffled ...................

Mrs. Leon Douglas. Begonia rose, striped scar-

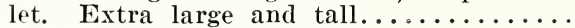

Mrs. Watt. Brilliant wine color...........

Mr. W. H. Phipps. Tall, beautiful flesh pink. .

Myra. (Prim.*) Deep salmon yellow. Early.

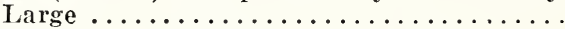

Nancy Hanks. Peach-red to orange pink.....

Orange Flame. A wondrous, glowing, vermillion orange. Very large. Blooms magnificently

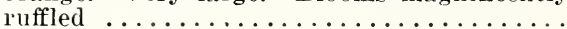

Orange Queen. Clear copper orange........ .15 1.50

Panama. Pure rose-pink. . . . . . . . . . . . . .

Peace. Beautiful large white. Tinted pink....

Pearl, The. Clear, soft pink. Early ........... $19 \quad 1.00$

Pink Wonder. Strong growing, handsome light ${ }^{15} \quad 1.50$ $\begin{array}{lll}\text { rosy pink. Very large } \ldots \ldots \ldots \ldots \ldots \ldots \ldots \ldots & .15 & 1.50 \\ \text { yanna. Clear golden yellow } \ldots \ldots \ldots \ldots \ldots & .25 & 2.00\end{array}$

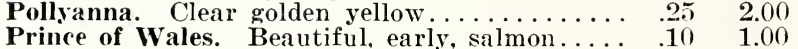


Purple Glory. Deepest, velvety maroon with almost black blotches. Ruffled, fine, strong. .\$ :20 \$2.0(1)

Rev. Ewbank. Exquisite porcelain blue ...... .20 2.00)

Richard Diener. Pale geranium pink. Ruffled. .15 1.50

Rosalia. (Prim.*) Ruffled. Yellow, blushed orange. Magnificent............... .10 1.00

Rose Ash. Corinthian red, fading to ashes of rose on outer edges. Very distinctive.....

Rose Glory. Ruffled rose pink. Very pretty...

Rose, 1910. Early bright rose with white lines.

Scarlano. Early, ruffled, scarlet orange......

Scarlet Princeps. Rich glowing scarlet. Large flower and spike.................

Schwaben. Sulphury yellow with red in throat.

Souvenir. (Prim.*) Clear, deep, golden yellow. Wonderful shade and form.............

Sweet Lavender. Early flowering. Lavender

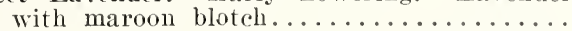

Thomas T. Kent. Shell pink, overlaid with strawberry. Crimson streak on petals...

Twilight. Ruffled. Beautifully blushed creamy buff. Strong growed and very fine. 2 for $25 \mathrm{c}$.

Ulrica. (Prim.*) Ruffled. Delicate rose pink, shading lighter. Large, excellent. 3 for $25 \mathrm{c}$.

Waneta. (Prim.*) Pink with white throat...

White Glory. Ruffled white with blue throat...

White Wonder. Large. Pure white. Vigorous

Wilbrink. Dainty pale pink. Early, large, and

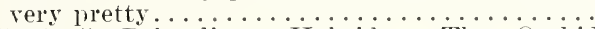

*"Prim." Primulinus Hybrids. The Orchid Gladiolas. Smaller and daintier, with graceful, slightly hooded flowers, in exquisite shades.

\section{LEMON LILIES}

Beautiful single yellow variety, $20 \mathrm{c}$ per plant, $\$ 2.00$ per dozen. (By mail, 25c each; $\$ 2.20$ per dozen.)

We want you to be one of our satisfied customers. We aim to more than please and we want you to send us your order for nursery stock not only this year, but next year. and in the years to come.

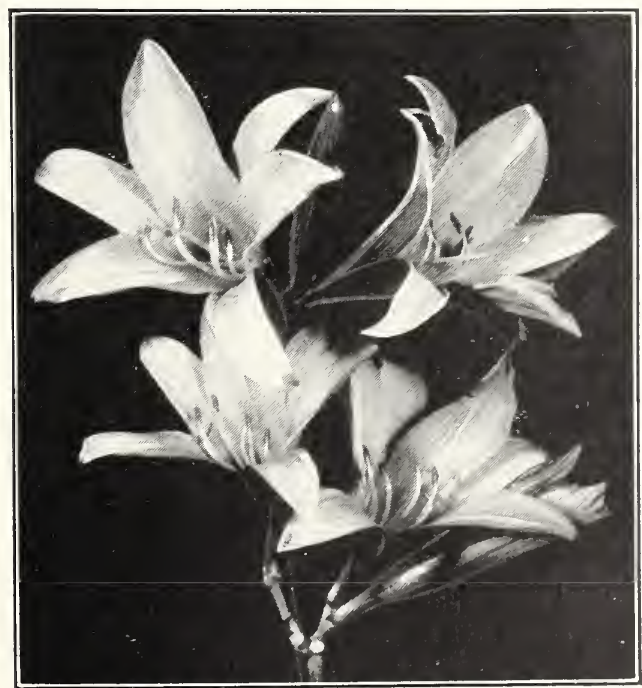

Lemon Lily 


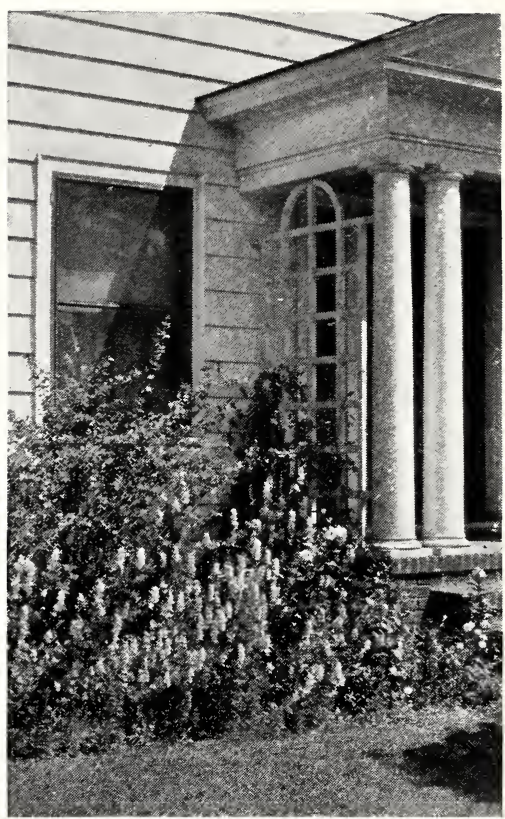

\section{HARDY PERENNIALS}

It matters not how small your garden, nor whether you own your own home or not, every flower lover should have some perennials. They are a great source of pleasure, requiring very little work, and yielding an abundance of flowers in great variety of form and color. Buy some of these especially choice varieties and you will be relieved of planting seeds or annual plants each year, and at the same time you may have flowers to admire in the garden and flowers to cut for the house.

If you are not familiar with the varieties and care to have us, we shall be pleased to send you an assortment of some of the best kinds.

Those varieties marked * are suitable for rock-garden planting if desired.

Except where otherwise noted, we can supply the following list of plants at 20c each; $\$ 2.00$ per doz., comprising not less than six plants of one variety. (By mail. 25 c each; $\$ 2.20$ per dozen.)

Please bring the total of your order to at least $\$ 1.00$.

* Achillea. The Pearl. $2 \mathrm{ft}$. Yields double white flowers all Summer long, suitable for cutting.

Aconitum. Monkshood. $3 \mathrm{ft}$. Dark blue flowers in August and September. 25c; $\$ 2.50$ doz.

Agrostemma. (Mullein Pink). $2 \mathrm{ft}$. Showy white foliage. Many pink-like flowers.

* Alyssum. Basket of Gold. A low, gray-leaved plant, covever with golden flowers in May.

Anchusa. 3-5 ft. Gentian-blue flowers in May. 25c.

Anthemis. Hardy Marguerite. $2 \mathrm{ft}$. Excellent for cutflowers all Summer. Spreads rapidly.

* Arabis. Rock Cress. 6 in. Covered with white flowers in April and May.

Artemesia. Silver King. 30 in. Bright silver-colored stems and foliage. Useful in perennial borler or among shrubbery. May be dried for Winter bouquets or used fresh. 25c; $\$ 2.50$ doz. 
Astilbe. 2-4 ft. Many feathered heads of thowers in June and July. 50c. Juno. Purplish rose; Kriemlilde, Salmon rose.

* Aubretia. Rainbow Rock Cress. (; in. Covered with bright flowers in spring and early summer.

Baptisia. (False Indigo). $2 \mathrm{ft}$. Dark green. deeply-cut foliage, and spikes of dark blue flowers. June.

Bee Balm. (Monarda). 2 ft. Bright scarlet. July-iugust,

Bleeding Heart. 2 ft. Red, heart-shaped flowers in long racemes. May. $50 \mathrm{c} ; 60 \mathrm{c}$ by mail.

Bocconia (Plume Poppy). G-S ft. Creamy white cones of flowers. July and August.

Boltonia. 4-6 ft. Many pink aster-like flowers in bloom at once. August to October.

*Buttercup, Double. $6-5$ in. Bright golden, double flowers in May and June.

Centaurea-See Corn Flower.

* Candytuft, Hardy. S-10 in. Evergreen foliage and dense heads of pure white flowers in Sirring.

Canterbury Bells. (Biennial). Blue, rose, white. 25̃c. $\$ 2.50^{\circ}$ doz.

* Columbine. $2 \mathrm{ft}$. Beautiful and graceful flowers in early Summer. White, blue and rose.

Coreopsis. $2 \mathrm{ft}$. An abundance of rich yellow flowers throughout the Summer. Very good for cutting.

Corn Flower. $2 \mathrm{ft}$. Violet-blue flowers from July to September.

Daisy, Persian. (Pyrethrum). 2 ft. Very pretty red, pink, and white flowers with fern-like foliage.

Daisy, Shasta. Large with flowers in Summer and Fall.

*Flax, Hardy. $2 \mathrm{ft}$. May and June. Beautiful blue flowers.

Foxglove. (Biennial). Blue. Rose. White. 25c, $\$ 2.50 \mathrm{doz}$.

Gallardia. Blanket Flower. 2 ft. Showy crimson and orange flowers with dark red centers. June to frost.

Geum. 15-1S in. Showy bright colored flowers. May to July.

Golden Glow. $6 \mathrm{ft}$. Abundance of rellow flowers, JulySeptember. 10c. $\$ 1.00$ per dozen.

Gypsophilla. Baby's Breath. 2 ft. Abundance of small, white flowers. July-August. 25c; $\$ 2.50$ doz.

Gypsophilla, Bristol Fairy. 2-3 ft. Double. Vigorous grower with large flower clusters. If kept cut, will bloom all season. 50c each. $\$ 5.00$ per doz.

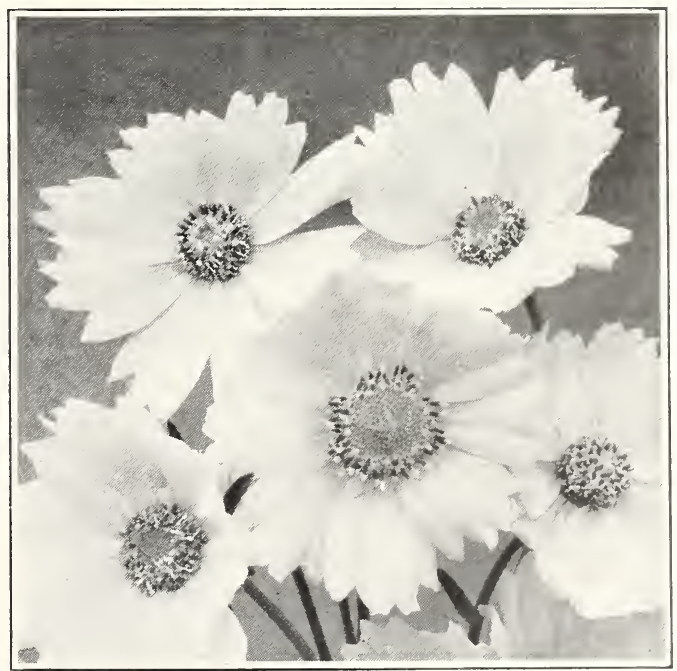

Coreopsis 


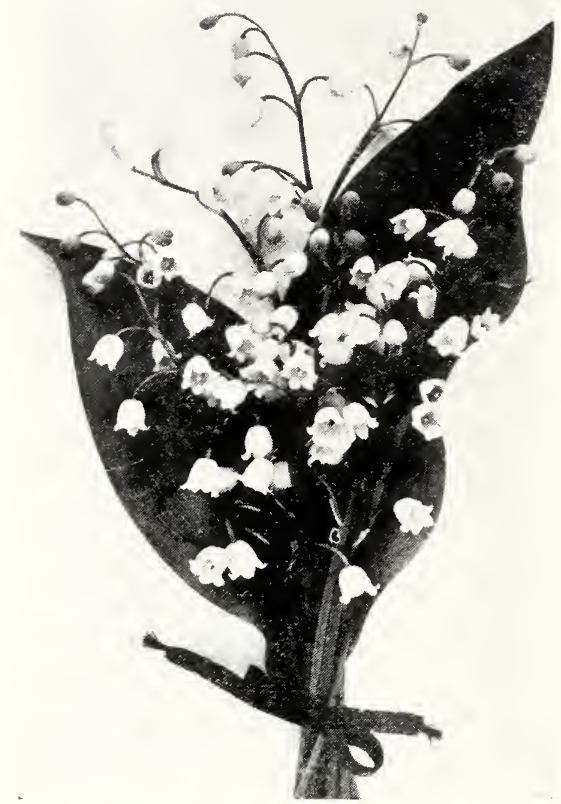

Lily-of-the-Valley

Helenim, Autumuale. (Sneezewort). $5 \mathrm{ft}$. Bronze flowers in August and September.

Helianthus. Hardy Sunflower. $5 \mathrm{ft}$. Decorative and good for cutting.

*Henchera (Coral Bells). 18 in. Profusion of coral red spikes in July and August. Fine for cutting. 35c. $\$ 3.50$ doz.

Hollyhork. 5-7 ft. Useful, tall-growing plants. White, pink, rose, yellow. Single and double. 25c; $\$ 2.50$ doz.

Iris, Bearded. May and June. Blue, white, yellow and purple. See special list, Pages 33 and 34 .

*Iris, Dwarf. Grows 6-12 in. high and blossoms early in May. 25c; $\$ 2.50$ per doz.

Iris, Japanese. See special list on Page 35.

Iris, Siberian. Deep blue flowers with grass-like foliage. $25 \mathrm{c} ; \$ 2.50$ per doz.

*Jacob's Ladder. (Polemonium). 18 in. Bell-shape blue flowers. May-June.

Lantern Plant, Chinese. Dense, bushy plant, bearing bright scarlet "lanterns" suitable for drying for Winter decorations. $25 \mathrm{c} ; \$ 2.50$ doz.

Larkspur. Tall spikes of beautiful blue during the Summer. Light and lark. 25c; $\$ 2.50$ dozen.

Liatris. Kansas Gayfeather. $3-5 \mathrm{ft}$. Long spikes of rich purple flowers in July and August. Very pretty. Good for cutting.

Lily, Day-White. $1 \frac{1}{2}-3$ ft. Large, golden-green leaves. Fragrant. $50 \mathrm{c} ; 5$ for $\$ 2.00 ; \$ 4.00$ doz.

Lily-of-the-Valiey. Beautiful, graceful flowers about Iemorial Day. Clumps, 40c each; 45c by mail.

Lily, Lemon. 3-4 ft. June-July. Beautiful, clear, yellow. Fine for cutting. 25c; $\$ 2.00$ per doz.

Lupine. $3 \mathrm{ft}$. Beautiful spikes. Blue, Pink, White June.

Lychnis. $1 \mathrm{ft}$ Brilliant red flowers in May and June.

Lythrum, Loose Strife. $3 \mathrm{ft}$. Spikes of rosy flowers. July to September. 
Peonies. See special list, Pages 202 and $2: 3$.

Penstemmon. (Beard Tongue). 2 ft. Mixed. Show spikes of flowers throughout the simmmer.

Phlox. See special list, I'age 32 .

*Pink, Clneddar. 3 in. Rosy pink flowers in May and June.

*Pink. Garden. Both single mixed and double mixed.

*Pink. Maiden. Creeping rariety with medium sized pink flowers. June-July.

Platycodom. $2 \mathrm{ft}$. Many fine flowers. July and ()e.t.

*Polyanthus. !) in. Free-flowering. Showy. Early spring.

Poppy, oriental. 3 ft. Immense and brilliant red flowers in May and .June. Should be planted early in the Spring or in the Fall. 25e: 30c by mail.

*Poppy, Iceland. 12 in. Many brilliant flowers useful for cutting. Blooms throughout the season if not allowerl to go to seed.

Potentilla (Cinquefoil). 18 in. Irofusion of rosy-red flowers. June-August.

Salvia. 3-t ft. Profusion of sky-blue flowers in AugustSeptember.

Saxifrage. $1 \mathrm{ft}$. Very effertive deep green foliage. Rosppink flowers in early spring.

scabiosa. Blue Bonnet. 3 ft. Soft lavender blue. Fine for cutting.

*Sea Pink. (Armeria or Thrift), 9 in. Rosy pink flowers all Summer. Good edging plant.

*Sedum, Acre. (Golden Moss). Foliage green. Bright yellow flowers.

*Sedum, Spurium. fin. Rosy erimson flowers in July and August. 25c; $\$ 2.50$ doz.

*Sedum. Stolonifera. $\quad$; in. Flat, sucrulent leaves. I'nrplish-pink flowers in .July and August.

snow-in-Summer. (Cerastium). $1 \mathrm{ft}$. Covered with bellshaped white blossoms in May and June.

*Soap-Wort. Low-glowing plant with small, bright roso flowers from May to Angust.

Statice. 11/2-2 lit. Large, feathery heads of minute purplish blue flowers. Fine for drying.

Stokesia, Cornflower Aster. 1s in. Iiears many bright lavender blue blossoms. June-September.

Sunflower. Orange. $3 \mathrm{ft}$. July-August. Beatiful deep gollen-yellow flowers suitable for cutting.

Sweet Rocket. (Hesperis). 2-3 ft. Spikes of sweet-serented flowers in May and June.

Sweet William. Very sweet flower heads with carnationclove fraglance. Jume-July. Scarlet. White I'ink.

Sweet William. Everblooming Hybrid. Swret William crossed with Anmual Pinks. Produces an abundance of intense crimson-scallet flowers.

*Tunica. Low-glowing tufted plant with light pink flowers all Summer.

Valeriana. (Garden Heliotrope), : -4 ft. Showy. demse chusters of leliotrope-scented flower's in Jume and July. 25e: $\$ 2.50$ (loz.

Veronica. Spicata Speedwell. 2-:3 it. Spikes of beantiful deep blue flowers. July-sentember. Yery nerter.

Veronica. Longifolia subsessilis. $2 \mathrm{ft}$ ('ompact flower spikes of deep blue. Ilistinct foliage. July-lugust. 2.5. each : $\$ 2.50$ per doz.

Vinca. Myrtle or Periwinkle. Glossy, evereresn foliagr. Extensively used for a ground cover, especially in sharly places.

*Viola. Jersey Gem. Corered with dark blue flowers from May to November. 25e: $\$ 2.00$ per doz.

Yucea. Idam's Needle. 万) ft. Spikes of fragrant, reamy white flowers. Jume-July. Evergreen, sworl-like foliage. $25 c ; 30 c$ by mail. 


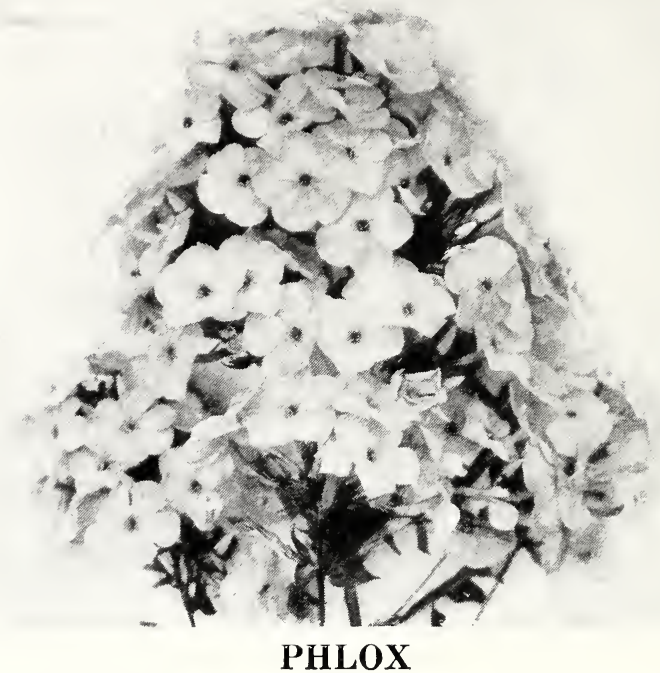

There are a wreat many varieties of phlox, some of them very desirable, and others almost worthless. The following assortment contains the ten varieties which the Experimental Gardens of the Department of Floriculture of Cornell University consider the most popular. In addition we offer Wm. Robinson, Embrasement, and Champs Elysees.

20 c each; $\$ 2.00$ per dozen. By mail, 25c each; $\$ 2.20$ per dozell, except as noted.

B. Comte. 30 in. Mid-season to late. Light aster purple to deep purple. Intense lustre. Amaranth purple eye. 30 c each; $\$ 3.00$ per doz.; 35e by mail ; $\$ 3.20$ per doz.

Champs Elysees. $2 \mathrm{ft}$. Dark purple. Mid-season.

Coquelicot. $30 \mathrm{in}$. One of the brightest scarlets. 25c; $\$ 2.50$ doz.; $30 \mathrm{c}$ by mail; $\$ 2.70$ per doz.

Eclaireur. 30 in. Early. Rhodamine purple with deep scarlet eye. Slightly fragrant.

Elizabeth Campbell. $2 \mathrm{ft}$. Mid-season. The best pink. Slight fragrance. $30 \mathrm{c}$ each; $\$ 3.00$ per doz.; $35 \mathrm{c}$ by mail ; $\$ 3.20$ doz.

Embrasement. $2 \mathrm{ft}$. A clear, soft rose color. Very popular with visitors in our gardens. Mid-season to late. 30c each; $\$ 3.00$ per doz.; 35c by mail ; $\$ 3.20$ doz.

Jules Sandeau. $2 \mathrm{ft}$. Mid-season. Deep Tyrian pink with Rhodamine purple eye. Distinct fragrance. Deep green foliage. Vigorous. $30 \mathrm{c}$ each; $\$ 3.00 \mathrm{per}$ doz.; $35 \mathrm{c}$ by mail; $\$ 3.20$ per doz.

La Vague. $2 \mathrm{ft}$. Mid-season to late. Shades from phlox pink to mallow purple. Very vigorous. Heavy, broarl, green foliage.

Miss Lingard. 30 in. Early white with faint red eye. Good bloomer.

Mrs. Jenkins. 30 in. Early. One of the best whites.

Rhinelander. 30 in. Mid-season. Begonia rose, Rhodamine purple eye. Slightly fragrant.

R. P. Struthers. $2 \mathrm{ft}$. Nid-season. Rose color with crimson eye. Slightly fragrant. 25c; $\$ 2.50$ doz; 30c by mail: $\$ 2.70$ per doz.

Richard Wallace. $2 \mathrm{ft}$. White with red eye.

Thor. $30 \mathrm{in.} \mathrm{Mid-season} \mathrm{to} \mathrm{late.} \mathrm{Deep} \mathrm{salmon} \mathrm{pink,} \mathrm{over-}$ laid with scarlet. Purple eye. Strong fragrance.

Wm. Robinson. Large salmon flowers. Recommended as one of the best by the Horticultural Experimental Farm of Canada, with Eclaireur, Elizabeth Campbell, Miss Lingard, and Thor on our list.

\section{DWARF PHLOX (Subulata)}

A useful ground-cover, with glossy green moss-like folinge. Does well in lot, dry places, and blooms profusely in April and May. May be used in the rock garden. Rose and White. 20c each; $\$ 2.00$ per doz. 


\section{BEARDED IRISES}

Commonly, though erroneously, called German Iris, These May-flowering, vigorous-growing plants thrive in welldrained, sunny spots. See them in bloom and you will know at once why they are increasing in popularity each year. In planting. barely cover the roots, and mulch the first Fall to prevent hearing.

Iris may be transplanted in the Spring, in the Summer $o r$ in the Fall -in short almost any time when the ground is not frozen.

Our stock of Iris is large, and a visit to our nurseries at blossoming time will well repay any who like to see them in bloom. We shall be pleased to have you call.

\section{SPECIAL OFFERS BEARDED IRISES}

25e varieties, 6 of one variety, $\$ 1.25 ; \$ 2.00$ for 12 . 35 c varieties, 6 of one variety, $\$ 1.75 ; \$ 3.50$ for 12 . $50 \mathrm{c}$ varieties, 6 of one variety, $\$ 2.50 ; \$ 5.00$ for 12 .

By mail, add 5e per plant, or $\ddot{3}$ each when 5 or more are ordered, or 25e per dozen.

(S. signifies "standards or upright petals; F., "falls" or drooping petals.)

Albert Victor. S., soft blue; F., beautiful lavender. Large and fine. 25c.

Ambassadeur. S., lavender. F., deep red-violet with orange beard. The aristocrat of the irises. Large and showy. $60 \mathrm{c} ; \$ 5.00$ for 12 .

Inna Farr. S., white, bordered pale blue. F., white. Good height and form. $60 \mathrm{c} ; \$ 5.00$ for 12 .

Aurea. Beautiful chrome yellow. Late. 35c.

Flavescens. Sulphur yellow, brown veins on falls. 25c.

Florentina. White, blue tint, large, fragrant. Early. 25e.

Her Majesty. S., old rose; F., white, striped with rosy-lilac. Large. 25c.

Kochi. S. and F. Rich claret-purple. Early and handsome. 35c.

La Neige. Pure white. Good grower and very pretty. 50c.

Lent A. Wiiliamson. S., violet. F., very large, velvetypurple. Brilliant orange beard. 50c.

Lohengrin. S. and F. Cattlya-rose. Large, strong grower and great bloomer. $25 \mathrm{c}$.

Loreley. S., light yellow; F., ultramarine with cream. 25e.

Madame Chereau. White with blue edge. 25c.

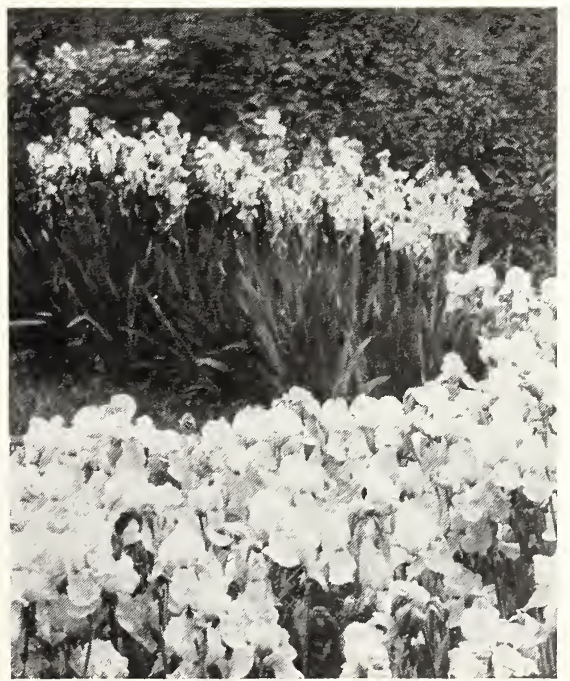


Massasoit. S. and $F$, distinct shade of metallic Venetian blue. 35.c.

Mitluas. S.. light yellow. F., brilliant wine-red with narrow border of deep yellow. Very showy. 25c.

Monsignor. S., rich. satiny violet. F., velvety purple-crimson with lighter margin. Iarge flowers. $25 \mathrm{c}$.

Motler-of-Pearl. S. and F., bluish lavender. A wonderful new rariety which suggests its name. A great bloomer. Tall and vigorous. $50 \mathrm{c}$.

Irs. Alan Gray. Free blooming. delicate rose mauve. 25c.

Mrs. H. Darwin. White with purple reins. 25c.

Opera. A great blooming. reddish purple. Very bright. 5oc.

Pallida Daîmatica. Tall. lavender blue. 25c.

Perfection. S., light blue. F.. dark velvety black with orange beard. $25 \mathrm{c}$.

Princess Victoria Louise. S., sulphur yellow. F., rich plum. bordered cream. $25 \mathrm{c}$.

Prosper Laugier. S., light bronze-red. F., velvety rubypurple. Beard white with yellow tip. Handsome. 25.

Prospero. Pale lavender standards: rich, deep violet-purple falls. 50c.

Queen Mlexander. S.. fawn. F., lilac. Tellow beard. 35c.

queen-of-May. S. and F., lovely, soft, rosy-riolet, nearly pink. 25c.

Rhein Nixe. S., white. F., violet blue with white edge. Tall. Large. $25 \mathrm{c}$.

Rose Unique. Bright old rose, almost pink. Very beautiful. $35 \mathrm{c}$.

Seminole. S., dark violet rose. F., rich, velvety crimson. ()range beard. 50c.

Sherwin Wright. Golden yellow. Free-flowering. vigorous grower. $25 \mathrm{c}$.

Souvenir de Madame Gaudicliau. Tery rich velvety purple. One of the rery best. Tall and of wonderful character. $\$ 1.00$.

Sumset. S. and F.. lavender bordered yellow. Yellow beard. 1 superior variety. 75 (c.

White Knight. Almost pure white. 35c.

White Queen. Snow white. a profuse and long-bloomer. 7.5.

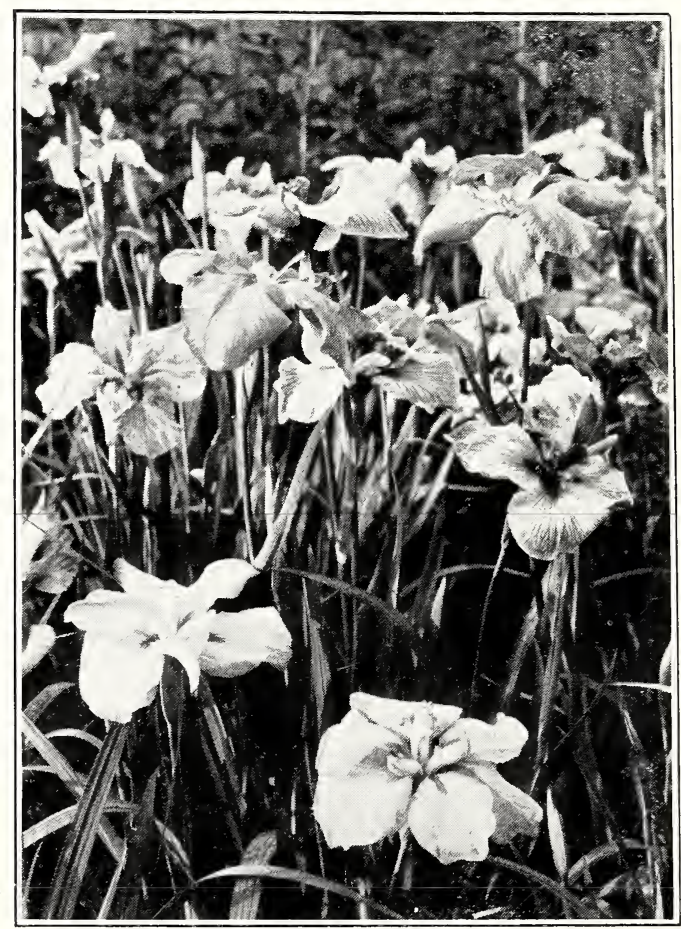

Japanese Iris 


\section{JAPANESE IRIS}

As garden-lovers are getting to know the Japanese Iris they are becoming very popular. This is deservedly so. for they are truly beautiful. They should NO'T be planted in low, damp places. While they like plenty of moisture in May and Jume, before blooming. they nust have good Winterdrainage.

In addition to the varieties listed here, we have other beautiful kinds which we offer at 50 each.

crders filled in the spring. Summer, and eally Fall.

$35 \mathrm{c}$ each : $\$ 3.50$ per doz.

\section{Description of Varieties}

No. 2 Falls lavender. Stands wine color. 3 petals. Large and fine.

No. 105 Six petals. bright crimson maroon.

No. 121 Three large maroon petals with yellow bar. Center wine color. Very double.

No. 129 Falls yellow blotch at center, shading into blue. Stands light lavender. Very pretty.

No. 130 Beautiful vinous purple veined white, orango blotch. Stands white. tipued purple. 3 petals.

No. $13 \pm$ Royal purple, sharled crimson. 6 petals.

\section{THE FOLLOWING CAN BE SHIPPED BI} PARCEL POST

$\begin{array}{ll}\text { Dwarf Fruit Trees } & \text { Shrubs } \\ \text { Peach Trees } & \text { Roots } \\ \text { Small Fruits } & \text { Vines } \\ \text { Grape-Vines } & \text { Rose Bushes } \\ \text { Isparagus and Rhubarb } & \text { Peonies } \\ \text { Gladiolus } & \text { Plants and Bulbs }\end{array}$

\section{MOTHER'S DAY}

Sunday. May 10, 1931

Why not ask us to send a flowering shrub, some gladiola bulbs, a tree, or some hardy flowering plants-such as phlox. larkspur, or the like, to Mother for Mother's Day? We shall be glad to attend to it.

The fragrant Evergreen Daphne (Page 1t) with its sucression of bloom throughout the season would be much appreciated.

\section{TREES AND PIANTS FOR THE NEW ENGLANI) ORCHARD AND GARDEN}

We offer good. clean. hardy and healthy stock of the best varieties for New England.

Direct selling on our part and direct buying on yours climinate the commissions paid to agents and give you the benefits of this saving.

\section{FALL PLANTING}

Fach Fall the number and volume of our sales exceeds that of the preceding Fall. Of course, Fall is the season to plant the bulbs which give so much pleasure in the Spring (tulips, crocuses, etc.), and the best time to set peonies, as vell as a good time to plant many other things. For a list of what you can plant in the Fall, see the following. and see our Special Fall Planting Circular which will be ready in the Summer.

What you don't plant this Spring, plant in the Fall, and send your order to us.

\section{WIITT YOI CAN PIANT IN THE FIIS,}

September and betober

\begin{tabular}{ll} 
Ieonies & Raspberries \\
Irises & Plackberries \\
Lemon Lilies & Rhubarb \\
Bleeding Heart & Perennials \\
\multicolumn{1}{c}{ Ortober and November } \\
Apple Trees & Shade Trees \\
Grape-Vines & Shrubs
\end{tabular}




\section{GARDEN FURNITURE}

Arbors, benches, garden houses, seats, chairs, trellises, etc. By arrangements with a nearby manufacturer we are able to furnish these things all set up and painted, or in sections, painted and ready to erect.

Further particulars on request.

Attractive Trellisses, $\$ 2.00$ each. Single lots, $\$ 2.25$, by express; 2 or more, $\$ 2.00$ each.

Picture two or three trellises around your home, covered with our Dr. Van Fleet, Climbing American Beauty, or I'aul's Scarlet Climbing Rose.

We shall be glad to supply you.

\section{VIGORO}

\section{A SWIF' \& COMPANY PRODUCT, ESPECIALLY PREPARED FOR LAWNS, GARDENS, FLOWERS SHRUBIERY, TREES. CLEAN, ODORLESS EASY TO APPLY}

Vigoro is recognized as one of the best complete, allaround fertilizers on the market. It will give good results on everything you grow. We can supply it in

$5 \mathrm{lb}$, cans

50 lb. bags

25 lb. bags

100 lb. bags

For the convenience of our patrons, we are prepared to apply fertilizers on lawns, etc., with the use of a machine. Or we will rent a machine to those who prefer to use one themselves, or have their own man use it.

\section{PRUNING SERVICES}

We are Registered Arborists with the Forestry and Agricultural Departments of the State of New Hampshire and are prepared to prune orchard and shade trees within convenient distance of Execter.

Much damage can be done to trees and shrubs by injudicious pruning. We suggest that you give this careful consideration and employ trained men.

\section{DELIVERY AND PLANTING SERVICE}

Wherever desired, we are glad to attend to the planting of such shrubs, trees, plants, etc., as we may furnish any of our customers within convenient trucking distance of Fxeter. Our trucks make several trips to Portsmouth, Manchester, Concord, Dover, Rochester, Newburyport, Haverhill, Amesbury, York Harbor, and other nearby points in Maine, New Hampshire and Massachusetts each season. Estimates gladly furnished on request.

\section{SPECIAL OFFER}

\section{GLAIDIOIA BULBS FOR AN 8-FT, BORIER}

100 Gladiola Bulbs planted 5 inches apart will plant a bed about $4 \mathrm{ft}$. square, or $2 \mathrm{ft}$. wide and $\mathrm{S} \mathrm{ft}$. long, or a bed about a foot wide and $16 \mathrm{ft}$. long.

Many people when we say "100 bulbs" think, "Oh, that's too many." But who can't find room for a bed $1 \mathrm{ft}$. wide and $16 \mathrm{ft}$. long, or room for two or three beds of shorter lengths?

Our EXONIAN MIXTURE is made up of very pretty varieties, in good assortment, taken from our list on pages 25, 26. 27. 100 first size bulbs, $\$ 1.50$ postpaid. 


\section{THE ACADEMY TOWN}

"BRITE AND FAIR"

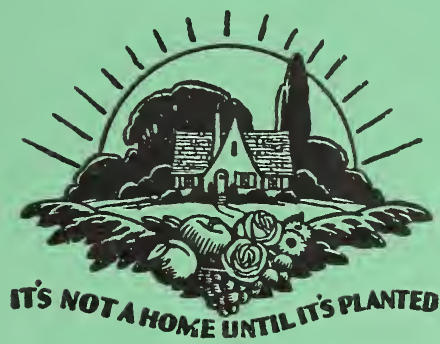

INDEX

Apple Trees........................ 2,3

Asparagus Roots.................... 8

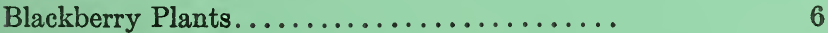

Cherry Trees........................ 3

Distances of Planting................. 6

Evergreen Trees.................... 11, 12

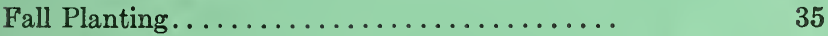

Fertilizer........................ 36

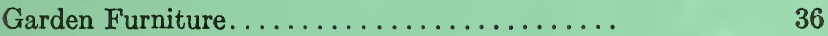

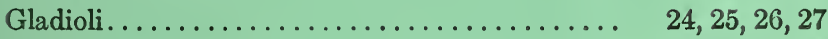

Grape Vines...................... 5

Hardy Perennials................. 28, 29, 30, 31

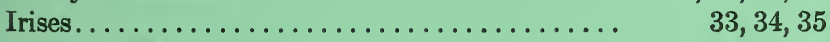

Lemon Lilies. . . . . . . . . . . . . . . . . . . . . 27

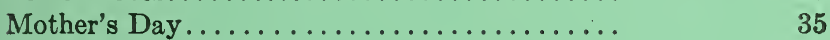

Parcel Post........................ 35

Peach Trees...................... 4, 5

Pear Trees......................... 4

Peonies....................... 22, 23

Phlox.......................... 32

Plum Trees........................ 4

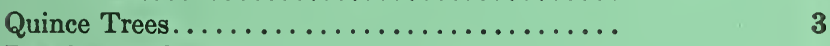

Raspberry Plants.................... 6

Rose Bushes................... 19, 20, 21, 22

Rhubarb Roots..................... 8

Shade Trees.................... 9, 10

Shrubs.......................13, 14, 15, 16, 17

Strawberry Plants................. 7,8

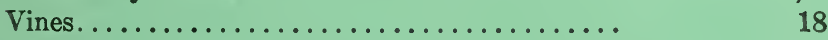

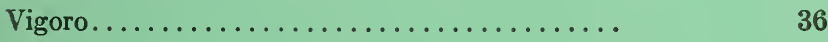

\section{INVITATION}

Visitors are welcome at the nursery. Come to see us especially in May and June when the Irises and Peonies are in bloom, and in July, August and September when the gardens glow with Gladiolas. 


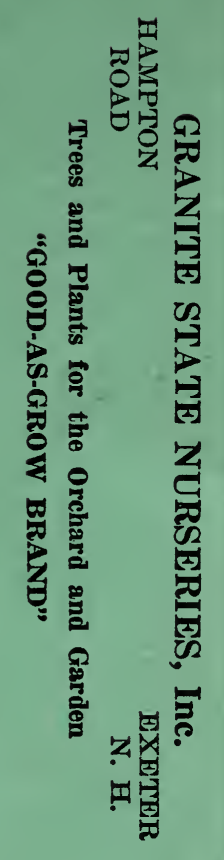

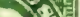

2.)

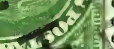

(1). 8

(1)

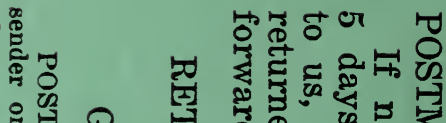

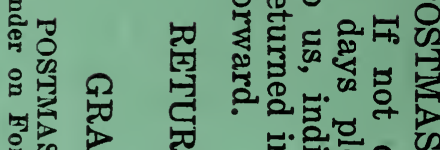

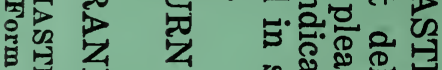

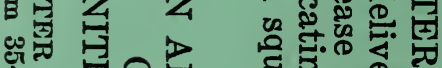

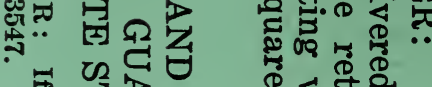

$\Rightarrow$ 饮点出

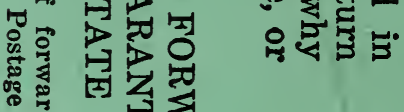

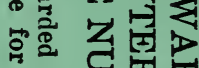

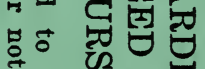

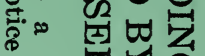

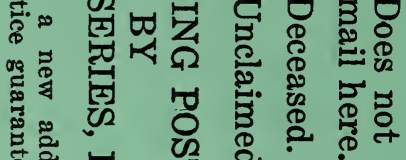

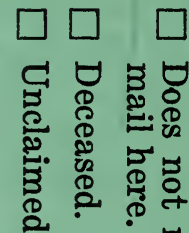

蛋 宫 号?

: ख्व

萬

进 